\title{
La administración desleal societaria en el Derecho penal español ${ }^{1}$
}

\author{
Diego-Manuel Luzón Peña \\ Raquel Roso Cañadillas \\ Universidad Álcala. Madrid, España \\ diegom.luzon@uah.es \\ rroso@gonzalezfranco.com
}

Fecha de recepción: 6 de marzo 2013 / Fecha de aceptación: 26 de agosto 2013

El trabajo analiza, dentro de la regulación del CP de 1995 de los delitos societarios, todos los elementos, objetivos y subjetivos, del tipo delictivo de la administración desleal societaria del art. 295, repasando críticamente las diversas posiciones doctrinales con respecto al bien jurídico, que se mantiene en este trabajo que es doble, del sujeto activo y de las modalidades comisivas, ofreciendo interpretaciones de sus elementos desde nuevos planteamientos, que influyen en la delimitación de los casos comprendidos en el tipo y en las relaciones concursales con la apropiación indebida. Defendemos la posición no mayoritaria de que en algunos casos excepcionales la comisión omisiva es equiparable a la activa tanto en la disposición de bienes como en la asunción de obligaciones perjudiciales. Se examina, lo que no está muy tratado en la doctrina española, la posible concurrencia de causas de justificación o exclusión de la tipicidad, como el consentimiento, el riesgo permitido en los negocios de riesgo o la insignificancia. En cuanto a la relación concursal con el delito de apropiación indebida, se fundamenta y sostiene, a diferencia de la doctrina y jurisprudencia dominantes, que no hay concurso de leyes o de normas, sino concurso de delitos, normalmente ideal.

administración desleal /apropiación indebida

1 Este trabajo, en lo sustancial, fue presentado como ponencia el 18.9.2009 por D.-M. Luzón dentro de la Tagung der Gesellschaft für Rechtsvergleichung in Köln, Fachgruppe Strafrechtsvergleichung (Präs. Prof. Weigend) y desarrolla y prosigue el trabajo iniciado en nuestro artículo publicado en España: Luzón Peña/Roso, Administración desleal, en Boix (dir.)/Lloria (coord.), Diccionario de Derecho Penal económico, Madrid, Iustel, 2008, pp. 29-68. El trabajo ha sido elaborado en el marco de nuestro proyecto de investigación 2008-02004/JURI: "Protección penal del sistema económico, empresarial y laboral en el marco de los mercados", financiado por el Ministerio de Ciencia e Innovación, Subdirección Gral. de Proyectos e Investigación. 
This paper analyzes, in the regulation of the Spanish Criminal or Penal Code (Código Penal, CP) 1995 of corporate crime, all the elements, objective and subjective, of the corporate offense of unfair administration or management of art. 295, critically reviewing the various doctrinal positions with regard to the legally protected interest, which we maintain in this paper is double, the active subject and the committing modalities, offering interpretations of its elements from new approaches, which affect the delimitation of the cases included in the legal description of the offence and the concurrence relations with the misappropriation or embezzlement. We defend the not majority position that in some exceptional cases the omitting commission is comparable to the active one in both the disposal of goods and the assumption of harmful obligations. We examine, which is not very discussed in the Spanish doctrine, the possible occurrence of justifications or exclusion of legal typicity, such as consent, allowed risk in risk business or insignificance or irrelevance. As for the relationship to the crime of misappropriation or embezzlement we base and maintain, in contrast to the prevailing doctrine and jurisprudence, there is no law or norm concurrence, but concurrence of offences, usually an ideal concurrence.

\section{Keywords}

Unfair administration or management/ missapropriation or embezzlement

\section{Tabla de contenido}

I. Regulación en el CP español. II. Bien jurídico. III. Tipo objetivo. 1. El sujeto activo o autor. 2. Acciones típicas. 3. El sujeto pasivo. 4. Abuso de funciones propias del cargo (infracción de deberes de lealtad. 5. Resultado de perjuicio. IV. Parte subjetiva del tipo. V. Causas de exclusión de la tipicidad y de justificación. VI. Iter criminis. VII. Autoría y participación. VIII. Concurso y delimitación con otros delitos. IX. Penalidad y perseguibilidad. Lista de Referencias

\section{Regulación en el CP español}


1. El delito de administración desleal tiene la siguiente redacción en el art. 295 del CP 1995 (Código Penal español de 1995)²: "Los administradores de hecho o de derecho o los socios de cualquier sociedad constituida o en formación, que en beneficio propio o de un tercero, con abuso de las funciones propias de su cargo, dispongan fraudulentamente de los bienes de la sociedad o contraigan obligaciones a cargo de ésta causando directamente un perjuicio económicamente evaluable a sus socios, depositarios, cuentapartícipes o titulares de los bienes, valores o capital que administren, serán castigados con la pena de prisión de seis meses a cuatro años, o multa del tanto al triplo del beneficio obtenido". Se encuentra situado en el Cap. XIII "De los delitos societarios", dentro de la segunda mitad del Título XIII "Delitos contra el patrimonio y el orden socioeconómico", ubicación que corresponde a los delitos que afectan al bien jurídico supraindividual orden socioeconómico además de o en vez de al patrimonio individual.

La administración desleal se tipificaba en todos los anteproyectos y proyectos anteriores (desde el Proyecto de CP 1980) al CP de 1995. No así en el anterior CP de 1944/1973, en el que los hechos que podían ser susceptibles de una administración desleal del patrimonio societario sólo se castigaban si constituían una apropiación indebida.

2. La creación del tipo de administración desleal societaria y su introducción en el CP de 1995 obedece a una necesidad real: la de dar una respuesta a una serie de prácticas ilícitas que contienen la suficiente entidad para no bastar la respuesta de las demás ramas del ordenamiento jurídico y legitimar, por ello, la intervención penal, pero cuya punición era antes imposible, porque, al tratarse de gravísimas infidelidades del administrador pero sin engaño previo al administrado y sin apropiarse tampoco de bienes, sus elementos no están incluidos ni en la estafa, ni en la apropiación indebida. Eso es lo que el legislador español hizo con la tipificación de la administración desleal, aunque sólo en el ámbito societario, en el art. 295 del CP, ante las peticiones reiteradas de doctrina y jurisprudencia, que ponían de relieve la insuficiencia del resto de delitos patrimoniales y la existencia entonces de una laguna legal ${ }^{3}$.

Aparte del tipo de la figura general de la administración desleal, los arts. 290294 contienen otros "delitos societarios". Por una parte se castigan diversos actos de administración ilícitos, como en el art. 294 el denegar o impedir la

Que la introdujo por primera vez en Derecho penal español, pues el anterior CP 1944/1973 no tipificaba éste ni los otros delitos societarios.

3 Así, por todos, Martínez-Buján, El delito societario de administración desleal, 2001, pp. 25 ss.; Mata y Martín, en: LH-Valle Muñiz, 2001, pp. 1546-1547. 
vigilancia o supervisión de la sociedad por las autoridades competentes, o formas específicas de administración infiel: en el art. 290 la falsificación de las cuentas anuales o de otros documentos importantes sobre la situación jurídica o económica de la sociedad como acto conexo con una posterior simultánea o anterior administración fraudulenta, y en el art. 293 el denegar o impedir determinados derechos de los socios por parte del administrador ${ }^{4}$. Por otra parte los arts. 291 y 292 castigan ciertos abusos graves de los socios. Aquí sin embargo sólo vamos a ocuparnos del tipo general de la administración desleal, y no de los otros delitos societarios ${ }^{5}$.

3. Fuera del ámbito societario se prevé asimismo en el actual CP, igual que se tipificaba ya en el art. 535 del anterior CP 1944/1973, el delito de apropiación indebida), regulado así en el art. 252: "Serán castigados con las penas del artículo 249 ó 250, en su caso, los que en perjuicio de otro se apropiaren o distrajeren dinero, efectos, valores o cualquier otra cosa mueble o activo patrimonial que hayan recibido en depósito, comisión o administración, o por otro título que produzca obligación de entregarlos o devolverlos, o negaren haberlos recibido, cuando la cuantía de lo apropiado exceda de cuatrocientos euros. Dicha pena se impondrá en su mitad superior en el caso de depósito necesario o miserable." ${ }^{6}$. Como se ve, en este precepto no se castiga la contracción perjudicial de obligaciones, pero tampoco cualquier disposición perjudicial de bienes ajenos por parte del administrador o de otro poseedor, sino sólo la apropiación o distracción de bienes (al respecto v. ampliamente infra III 2.1. a, VIII. 1).

E1 art. 293 CP supone por ello la realización de específicas formas de deslealtad del administrador frente a los socios a los que impide el ejercicio de Derechos. Art. 293: "Los administradores de hecho o de derecho de cualquier sociedad constituida o en formación, que sin causa legal negaren o impidieren a un socio el ejercicio de los derechos de información, participación en la gestión o control de la actividad social, o suscripción preferente de acciones reconocidos por las Leyes, serán castigados con la pena de multa de seis a doce meses".

5 En general sobre los delitos societarios en el CP español cfr. (para indicaciones más completas v. infra en la Bibliografía) Bacigalupo, en: Bacigalupo (dir.), Curso de DP económico, 1998, pp. 129 ss.; Bajo, in: $\mathrm{AaVv}$, La actividad empresarial desde la perspectiva del nuevo CP español, 1997; Díaz Echegaray, La responsabilidad penal de los socios y administradores, 1997; Faraldo, Los delitos societarios, 1996; Los delitos societarios. Aspectos dogmáticos y jurisprudenciales, 2000; Fernández Teruelo, Los delitos societarios en el CP español, 1998; García Cavero, La responsabilidad penal del administrador de hecho de la empresa: criterios de imputación, 1999; García de Enterría, Los delitos societarios. Un enfoque mercantil, 1996; Martínez-Buján, DP económico, Parte Especial, 1999, pp. 171 ss.; DP económico y de la empresa, Parte Especial, 2. a ed., 2005, pp. 339 ss.; Mata, en RDS 5, 1995, pp. 164 ss.; Moya, La responsabilidad penal de los administradores: Delitos societarios y otras formas delictivas, 2007; Rodríguez Ramos, en: BICAM, 1, 1996, pp. 71 ss.; del Rosal, Los delitos societarios en el CP de 1995, 1998; Sánchez Alvarez, Los delitos societarios, 1996; Serrano Butragueño, en AJA 48 1992, pp. 1 s.; Terradillos, Empresa y Derecho Penal, Buenos Aires, 2001; Valle/Quintero/Morales, De los delitos societarios, en: Quintero (dir.)/Morales (coord.), Comentarios a la Parte especial del Derecho

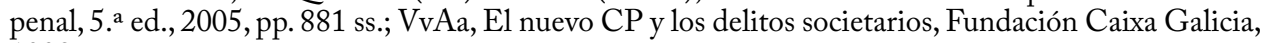
1998.

6 Prescindimos aquí de las modalidades especiales de apropiación indebida de cosa perdida del art. 253 y de cosa entregada por error del art. 254 . 


\section{Bien jurídico}

Para la mayoría de la doctrina el bien jurídico es el patrimonio -la mayoría de las veces tanto el patrimonio social como el de los socios- y no así el derecho de propiedad $^{7}$, que se salvaguarda por otros tipos como el de la apropiación indebida, que para muchos autores y jurisprudencia está muy cercano a la administración desleal ${ }^{8}$. Ello es cierto, con las matizaciones que ahora veremos. Pero además en este tipo se preserva de manera indirecta la estabilidad del tráfico económico: de manera indirecta porque a nuestro juicio lo que adicionalmente se protege de modo directo es la fiabilidad del funcionamiento correcto de las sociedades, que a su vez condiciona el funcionamiento del sistema económico.

1. Efectivamente con este tipo se asegura y salvaguarda un bien jurídico supraindividual: se suele aludir a la tutela del sistema económico y su estabilidad ${ }^{9}$, pero si concretamos más, hay que referirse al funcionamiento no del propio sistema económico, sino a la fiabilidad del correcto funcionamiento del sistema societario, de las sociedades como parte y pieza importantísima en la actualidad del sistema económico de un país (en régimen de economía de mercado, pero incluso también en los sistemas de economía mixta: colectivista/de mercado).

En la administración fraudulenta por tanto se protege por una parte el patrimonio tanto social, como el patrimonio de los socios y de terceros equiparados (cuentapartícipes, depositarios, titulares de valores o bienes administrados), pero por otra también el correcto funcionamiento de las sociedades, del sistema societario, la fiabilidad de las sociedades, del sistema societario para la comunidad, como bien juridico colectivo o supraindividual ${ }^{10}$.

Ambos bienes jurídicos van de la mano, porque no se castiga sin más el menoscabo del patrimonio individual, sino el de muchas personas (socios y otros terceros) junto con el patrimonio social, y además mediante la infracción por

Por todos, Mayo Calderón, La tutela de un bien jurídico colectivo por el delito societario de administración fraudulenta, 2005, pp. 9 ss.

8 Faraldo Cabana, Los delitos societarios, 1996, pp. 570, 584-585; Los delitos societarios, 2000, pp. 356 ss.; Martínez-Buján Pérez, El delito societario de administración desleal, 2001, pp. 26 ss., 96 ss.; Castro Moreno, El delito societario de administración desleal, pp. 299 ss., 467 ss. En la jurisprudencia: STS 224/1998, 26-2 (caso Argentia Trust); siguiéndola y desarrollándola STS 9272/2000, 15-12, STS 8984/2002, 29-7 (caso Banesto).

$9 \quad$ Así Rodríguez Montañés, La responsabilidad penal del administrador desleal, 1997,pp. 134 ss.; Mata y Martín, Bienes jurídicos intermedios, 1997, pp. 64-65; Fernández Teruelo, Los delitos societarios, 1998,pp. 103 ss.; Martínez-Buján, El delito societario de administración desleal, 2001, p. 32. Se alude también por parte de la doctrina a otros bienes jurídicos colectivos: cfr. por todos, Mayo Calderón, La tutela de un bien jurídico colectivo, 2005, pp. 10 ss., 219 ss., 228 ss., 260 ss., que defiende como bien jurídico la "permanencia de la sociedad en el tráfico jurídico-económico".

10 Así Luzón/Roso, en Boix (dir.)/Lloria (coord.), Diccionario DP económico, 2008, pp. 33 s. 
el administrador de un deber fundamental dentro de las relaciones societarias y consagrado por la legislación mercantil de sociedades: el deber de lealtad en la gestión de la sociedad y de los intereses patrimoniales de ésta y de los socios de modo que no se les causen daños indebidos, produciendo como efecto secundario el consiguiente perjuicio para terceros, empleados y acreedores; la expectativa y razonable seguridad de que no se producirá tal vulneración del deber de lealtad en la gestión social con sus indeseables repercusiones para terceros dentro del tráfico jurídico es la base de la confianza de la comunidad en el correcto funcionamiento del sistema societario.

El aspecto supraindividual del bien jurídico tutelado en la administración desleal societaria es la base fundamental para sostener que, si la gestión desleal del administrador de una sociedad consiste en una forma especialmente grave de disposición fraudulenta como es la apropiación de bienes de la sociedad, existe, no un concurso de leyes, sino un concurso ideal de delitos entre apropiación indebida del art. 252 y administración desleal societaria del art. 295: v. infra VIII.1.

2. Para terminar con esta cuestión, si ponemos en conexión el bien jurídico individual, el patrimonio, con los sujetos pasivos relacionados con el propio tipo, se pueden sostener las siguientes posiciones:

a) Algunos autores sostienen que el patrimonio, como bien jurídico protegido, no es el social, sino el individual de cada uno de los sujetos pasivos mencionados en el art. 295 CP: socios, depositarios, cuentapartícipes o titulares de los bienes, valores o capital. El patrimonio social sería entonces el objeto material y el patrimonio individual de socios o asimilados el bien jurídico tutelado, dada la falta de mención expresa de la sociedad como afectada por la administración fraudulenta ${ }^{11}$.

b) En cambio, la mayoría de la doctrina considera que el patrimonio social es el bien jurídico protegido por la propia naturaleza de las cosas y que hay que bordear en este punto la mala técnica legislativa, pues se argumenta que está claro que para dañar el patrimonio de los socios, cuentapartícipes y demás sujetos pasivos señalados hay que lesionar el patrimonio social y parece imposible dañar los patrimonios individuales, sin lesionar el patrimonio social ${ }^{12}$.

11 Nieto Martín, El delito de administración fraudulenta, 1996, p. 254; Castro Moreno, El delito societario de administración desleal, 1998, pp. 184-185; Martínez-Buján, El delito societario de administración desleal, 2001, p. 32.

12 Cfr. Faraldo Cabana, Los delitos societarios, 2000, p. 326. 
c) En nuestra opinión, se puede ofrecer una tercera alternativa, que parece la más correcta, ya que es posible sostener que se protege tanto el patrimonio de los socios o equiparados como el de la sociedad: alternativamente en la disposición fraudulenta de bienes; y en la asunción de obligaciones el patrimonio de socios o equiparados por sí solo o conjuntamente con el de la sociedad ${ }^{13}$ (v. infra III 3 b)

d) Por último, conceptualmente la disposición de bienes sociales también podría resultar fraudulenta únicamente para intereses patrimoniales de terceros como acreedores o empleados; pero como veremos (infra III d), por diversas razones debe descartarse que se proteja el patrimonio de terceros en sí mismo, es decir, si su afectación no va unida a la del patrimonio social o como repercusión de la defraudación del patrimonio de socios o equiparados.

\section{Tipo objetivo}

1. El sujeto activo o autor del delito de administración desleal no puede ser cualquiera, sino el administrador de derecho o de hecho o los socios.

a) Por ello nos encontramos ante un delito especial propio y no impropio, porque no hay ningún delito común paralelo en el $\mathrm{CP}$ con el que mantenga la administración desleal una relación de especialidad, ni siquiera la apropiación indebida ${ }^{14}$.

b) Administrador de derecho es quien ejerce individual o colegiadamente, p. ej. dentro de un consejo de administración, de modo permanente la función de administrar la sociedad reuniendo todos los requisitos y formalidades legales en cuanto a su nombramiento, inscripción, duración de su cargo, etc.

Pero el CP quiere además reconocer la condición de autor al administrador de hecho. Sobre este concepto existen dos interpretaciones: una restrictiva, defendida sobre todo por mercantilistas, que entiende que sólo es administrador de hecho aquel sujeto que desempeña legítimamente y con el correspondiente nombramiento de los socios, de la junta general, etc. el cargo de administrador, pero faltándole algún requisito formal, como la inscripción registral o la publicación en el

13 Cfr. Luzón/Roso, en Boix (dir.)/Lloria (coord.), Diccionario DP económico, 2008, pp. 36 ss.

14 Cfr. en detalles Luzón/Roso, Concurso entre apropiación indebida y administración desleal, en Boix (dir.)/Lloria (coord.), Diccionario DP Económico, 2008, pp. 181 ss. 
boletín del Registro mercantil, o dándose alguna otra irregularidad, como el título caducado por haber excedido del tiempo de su mandato, que impiden considerarlo administrador de derecho ${ }^{15}$. Y existe una interpretación más amplia, mayoritaria entre los penalistas y que compartimos ${ }^{16}$, según la cual es administrador de hecho todo el que fácticamente, incluso sin nombramiento expreso, desempeña con continuidad las funciones de administrador de esa sociedad ${ }^{17}$.

c) Es muy polémica la inclusión del socio dentro de los sujetos activos, pues en la realidad societaria los socios no tienen un papel de gestores, ni tienen la competencia, ni la posición dentro del organigrama social para llevar a cabo labores de gestión o de administración.

No son atribuciones que vayan unidas a su condición y hay que buscar situaciones específicas en el que el socio detente una cierta capacidad de gestión ${ }^{18}$ :

Así en los casos de sociedad en formación o sociedades personalísimas o cuando el capital social tiene como titular al único socio o cuando no se haya estipulado el modo de administrar (art. $1695 \mathrm{CC})^{19}$. También se podría pensar que el término admite no sólo al socio como persona física, sino al socio como órgano colegiado, es decir, el órgano social que corresponde a la Junta General o equivalente y entraríamos en el terreno de las decisiones colegiadas y de los acuerdos tomados en su seno. Acuerdos que pueden consistir en administraciones desleales del patrimonio social y que el administrador ejecuta como factotum (aunque puede seguir teniendo responsabilidad mercantil: cfr. art. 133 LSA, 69 LSRL) ${ }^{20}$.

En cualquier caso, los supuestos señalados, en donde se ponen en práctica con cierta continuidad estas facultades por el socio, también entrarían en el concepto de administrador, ya sea de hecho o de derecho, y no habría habido ninguna necesidad de hacer mención expresa al socio.

15 Así García de Enterría, Los delitos societarios, 1996, p. 46; Rodríguez Montañés, La responsabilidad penal del administrador desleal, 1997, pp. 114-115; García Cavero, La responsabilidad penal del administrador de hecho, 1999, pp. 112 s., 247-248; Nieto Martín, El delito de administración fraudulenta, 1996, pp. 270-271.

16 V. Luzón/Roso, en Boix (dir.)/Lloria (coord.), Diccionario DP económico, 2008, p. 39.

17 Así Bajo/Bacigalupo, DP económico, 2001, pp. 103-104; Mayo Calderón, La tutela de un bien jurídico colectivo, 2005, pp. 332 ss.

18 Cfr. Luzón/Roso, en Boix (dir.)/Lloria (coord.), Diccionario DP económico, 2008, p. 39.

19 Cfr. para más detalles Nieto Martín, El delito de administración fraudulenta, 1996, p. 268; Rodríguez Montañés, La responsabilidad penal del administrador desleal, 1997, p. 123; Martínez-Buján, El delito societario de administración desleal, 2001, pp. 67-68.

20 Cfr. Moreno Cánoves/Ruíz Marco, Delitos socioeconómicos, 1996, p. 337. 
Pero en los casos en que el socio no detenta ningún cargo dentro de la sociedad, no se entiende en absoluto cómo éste puede abusar de las funciones propias de su cargo, si no tiene cargo alguno. Por ello procede efectuar una interpretación restrictiva de la referencia a los "socios" (basada a su vez en una interpretación estricta de la exigencia de abuso de las funciones del cargo), en el sentido de que han de ser también administradores, aunque sea de hecho. No basta por tanto que un socio se arrogue momentánea e indebidamente un acto de gestión o de administración de la sociedad, sino que ha de tratarse justamente de socios que actúen "con abuso de las funciones propias de su cargo", como taxativamente requiere en todo caso el precepto; y tales socios a que se refiere el art. 295 sólo pueden ser los que estén simultáneamente desempeñando con continuidad, aunque sea de modo compartido con otros administradores, funciones de administrador de derecho o al menos de hecho, que es quien tiene deberes de gestionar con lealtad, y es por tanto el cargo societario en el que se puede actuar abusando de funciones propias del mismo ${ }^{21}$. Por esa razón además se sanciona en el 295 a los socios en pie de igualdad con los administradores.

No obstante, hay que reconocer que, de este modo, la mención expresa al socio no es más que un recordatorio de que éste puede desempeñar la posición de administrador, pero resulta realmente superflua ${ }^{22}$.

\section{Acciones típicas}

La acción típica viene descrita de un modo alternativo: disponer fraudulentamente de los bienes de la sociedad o contraer obligaciones a cargo de ésta. Se trata pues de un tipo mixto; el que se considere tipo mixto alternativo o cumulativo, o sea que la realización no de una sino de las dos conductas típicas se considere un único delito (concurso de leyes: consunción de los actos co-penados) o por el contrario concurso de delitos, es una cuestión de interpretación (sobre la solución de la misma v. infra VIII. 2).

2.1. Disposición fraudulenta. La primera de las acciones descritas es la disposición fraudulenta de los bienes de la sociedad.

21 Así Mayo Calderón, La tutela de un bien jurídico colectivo, 2005, p. 338; Luzón/Roso, en Boix (dir.)/ Lloria (coord.), Diccionario DP económico, 2008, p. 40.

22 Lo consideran así Moreno Cánoves /Ruíz Marco, Delitos socioeconómicos, 1996, pp. 336-337; Rodríguez Montañés, La responsabilidad penal del administrador desleal, 1997, pp. 122-123; Mayo Calderón, La tutela de un bien jurídico colectivo, 2005, p. 336; Luzón/Roso, en Boix (dir.)/Lloria (coord.), Diccionario DP económico, 2008, pp. 40 s. 
a) Disposición de bienes sociales. Aquí nos encontramos con el problema de decidir si esta actuación: la disposición fraudulenta, es o no coincidente con las de la apropiación o distracción de dinero, efectos, valores, etc. que constituyen las acciones típicas de lo que la ley considera una apropiación indebida en el art. 252.

a') La discusión se centra en los verbos típicos y sobre todo en dilucidar si 'disponer' se entiende como un acto de dominio que lleva aparejado ya en sí mismo el incumplimiento definitivo de la obligación de entregar o devolver, o si por el contrario, siguiendo a la mayoría de la doctrina ${ }^{23}$, se describe (en palabras de FARALDo) como la utilización o aprovechamiento por los administradores, en beneficio propio o de un tercero, de los bienes que integran el patrimonio social, sin que la sociedad obtenga compensación alguna, pero excluida siempre la posibilidad de atribución de dominio definitivo, que obligaría a entender presente la apropiación indebida ${ }^{24}$.

b’) Nuestra interpretación coincide en parte, pero sólo en parte, con la de la doctrina mayoritaria ${ }^{25}$. Coincide en que también hay actos de disposición distintos de la apropiación o de la distracción de efectos: así, los actos de disposición temporal y no definitiva; o aquellos actos de disposición parcial de las facultades dominicales sobre los bienes y que no impliquen adueñamiento definitivo, constituyendo sobre los mismos derechos reales tales como gravámenes de garantía (p.ej. hipotecas) o sujeción a otros derechos reales limitadores del uso o disfrute, como usufructos o servidumbres, o mediante la sujeción de los bienes a derechos obligacionales o de crédito como el arrendamiento; o finalmente los actos de disposición definitiva (como la venta) sin despojo total pero en condiciones desventajosas (aunque este último supuesto es considerado desde otra posición como auténtica apropiación indebida (cfr. infra 2.1 a c’2). Este verbo típico del art. 295 -disponer de bienes- no es idéntico, sino más amplio que los verbos utilizados en el art. 252, apropiarse o distraer, y supone por tanto, respecto de las acciones previstas en la apropiación indebida, una ampliación de las conductas típicas abarcando también acciones menos graves en sus repercusiones, lo que (unido a que aquí el perjuicio causado no ha de exceder de $400 €$ para constituir delito como en la apropiación indebida) explica que sea algo más benigna la pena de la administración desleal.

23 P. ej., Martínez-Buján, El delito societario de administración desleal, 2001, pp. 46-48; Gómez-Jara, La administración desleal de los órganos societarios, 2008, pp. 181 ss.

24 Así textualmente Faraldo Cabana, Los delitos societarios, 1996, p. 570.

25 Sobre lo que sigue cfr. Luzón/Roso, en Boix (dir.)/Lloria (coord.), Diccionario DP económico, 2008, pp. 41 ss. 
Pero no coincide nuestra posición con la mayoritaria en la medida en que ésta sostiene que los actos de disposición fraudulenta del art. 295 no pueden consistir en apropiarse o distraer, pues -se argumenta- de otro modo el delito de administración desleal no tendría entidad propia y se confundiría con el delito de apropiación indebida ${ }^{26}$.

Esto no es admisible. En efecto, las actuaciones de apropiación o distracción de bienes sociales que, siendo de carácter dominical y teniendo una apariencia de legitimidad y regularidad, implican un incumplimiento definitivo de la obligación de entregar o devolver, son apropiaciones indebidas, pero también simultáneamente administraciones desleales societarias, pues implican eo ipso un acto de disposición fraudulenta de bienes. No hay acto de disposición de bienes más claro ni mayor deslealtad y fraude en la administración que la indebida y definitiva disposición dominical de apropiación de los bienes o distracción del dinero o efectos por el administrador social.

Pero por eso mismo, como con esa acción también se realiza el tipo del delito (más grave) de apropiación indebida del art. 252 si la disposición excede de 400 $€,-$ apropiación indebida que es totalmente independiente de la administración de una sociedad-, hay un concurso ideal entre ambos delitos, la administración desleal societaria y la apropiación indebida, y no simplemente un concurso aparente o de leyes entre los arts. 295 y 252, ya que ninguno de los tipos delictivos abarca todo el desvalor de acción y de resultado y todos los bienes jurídicos afectados por tal conducta (v. infra VIII).

c') Otros supuestos dudosos ${ }^{27}$ :

1) Un administrador vende a un precio ventajoso, generando beneficios para la sociedad, pero sin autorización ${ }^{28}$. De entrada habría disposición definitiva indebida y se puede entender entonces que ha habido un perjuicio para la sociedad: en la pura venta no autorizada aunque sea a precio correcto o ventajoso habrá siempre un perjuicio jurídico por perder la sociedad la propiedad de un bien que no quería perder.

26 Un desarrollo de esta cuestión se puede ver en: Martínez-Buján, E1 delito societario de administración desleal, 2001, pp. 45 ss.

27 Sobre lo que sigue cfr. Luzón/Roso, en Boix (dir.)/Lloria (coord.), Diccionario DP económico, 2008, pp. 44 ss.

28 Consideran el caso como disposición fraudulenta, en supuestos muy parecidos, Castro Moreno, El delito societario de administración desleal, 1998, pp. 318 ss.; Martínez-Buján, El delito societario de administración desleal, 2001, pp. 55-56; Rodríguez Montañés, Administración societaria fraudulenta, 2002, p. 285; STS 8984/2002, de 29-7 (caso Banesto). En contra: cfr. por todos, Mayo Calderón, La tutela de un bien jurídico colectivo, 2005, pp. 316 ss. 
Ciertamente que ese perjuicio no es directamente un perjuicio económicamente evaluable, sino sólo indirectamente (porque, aun habiendo obtenido un buen precio, si el vendedor muestra su interés en re-comprar, ello producirá normalmente un aumento y encarecimiento para el precio de la nueva venta). Una parte de la doctrina considera que el requisito típico de actuar "causando directamente un perjuicio económicamente evaluable a sus socios" y asimilados afecta por igual a las dos modalidades de acción típica ${ }^{29}$; y en tal caso aquí no habría delito en el administrador por faltar la causación de un perjuicio directamente económico. Pero es más correcto entender que el requisito de directo perjuicio económico va vinculado directa y únicamente a la asunción de obligaciones, la segunda alternativa de conducta típica (v. infra 2.2), mientras que tal resultado no se requiere en la primera alternativa, en la disposición de bienes de la sociedad ${ }^{30}$ :

En contraposición a la asunción de obligaciones, que requiere daño económico directo, en la disposición de bienes, por su mayor repercusión jurídica como tal (modificación de la situación de cosas y derechos reales), el tipo se conforma con que sea "fraudulenta", es decir-aparte de con mala fe-perjudicial, que produzca perjuicio a la propia sociedad o a los socios o equiparados; y basta que dicho perjuicio sea jurídico, aunque no sea directamente económico.

2) El administrador con atribuciones para llevar a cabo una compraventa, vende la cosa por menor precio de su valor. La venta vuelve a suponer un acto de dominio, pero si esta clase de negocios jurídicos está contemplada dentro del ámbito de sus funciones, en principio, no habrá apropiación indebida, ya que no ha habido un adueñamiento no autorizado, sino sólo administración desleal ${ }^{31}$.

Ahora bien, pasando a las circunstancias concretas del negocio jurídico, si el precio de venta fuera tan excesivamente bajo que casi equivaliera a una donación, entonces sin duda hay que entender que el acto se convierte en un adueñamiento no autorizado con total despojo del bien a la sociedad propietaria: en tal caso habría una apropiación indebida del art. 252 al mismo tiempo que administración desleal del art. 295. Pero incluso cuando el precio de venta sea claramente inferior al normal, aun sin llegar a ser ínfimo, cabe sostener que, salvo en casos de pequeña inferioridad respecto del precio normal, sí existe

29 Cfr por todos Quintero/Morales, en Quintero (dir.)/Morales (coord.), Comentarios a la PE, 8. a ed., 2009, p. 921; Martínez-Buján, El delito societario de administración desleal, 2001, pp. 38 ss., 56.

30 Así Luzón/Roso, en Boix (dir.)/Lloria (coord.), Diccionario DP económico, 2008, pp. 44 s. En contra una buena parte de la doc. y jurispr., que opina que la exigencia de daños económico directo afecta a ambas modalidades de acción típica: v. supra n. 28.

31 Así, rechazando como regla la apropiación indebida pero aceptando administración desleal: Mayo Calderón, La tutela de un bien jurídico colectivo, 2005, pp. 316-317. 
también apropiación indebida; o bien, formulado de otro modo seguramente más plausible, que ello es así cuando la desventaja es considerable en un grado que se puede entender que el poder o acuerdo de autorización para enajenar se supedita implícitamente a que la venta no se haga en condiciones que puedan considerarse infundadamente desventajosas. Pues bien, en aquellos supuestos de venta tan desventajosa para la sociedad que puedan considerarse como venta no autorizada con adueñamiento indebido del bien (en el fondo donación bajo apariencia de venta), la administración desleal convierte a la compraventa en una apropiación indebida ${ }^{32}$, porque consiste en una apropiación fraudulenta en el momento en que trae causa de una falta de autorización y hay que aplicar un concurso ideal entre ambos delitos, pero para la doc. mayoritaria concurso de leyes (v. infra VIII.1).

3) $\mathrm{El}$ administrador, sin competencia para ello, vende bienes sociales $y$, como en el caso anterior, a un precio muy inferior al de mercado. La solución es idéntica a la del supuesto anterior, es decir, que habrá concurso ideal de delitos entre el de apropiación indebida ${ }^{33}$ y el de administración desleal societaria.

b) "Fraudulentamente" es un concepto de carácter mixto, objetivo y subjetivo ${ }^{34}$. Como veremos más ampliamente a continuación, por una parte supone disponer de bienes defraudando y perjudicando legítimos intereses patrimoniales (de la sociedad o de socios y asimilados), y por otra parte implica la connotación subjetiva de la mala fe.

1) Ciertamente también se puede interpretar sólo subjetivamente el concepto ${ }^{35}$, sosteniendo que significa actuación de mala fe (aunque no necesariamente engañosa).

2) Pero cabe y parece correcta, combinada con el integrante subjetivo de la mala fe, una interpretación objetiva de "disposición fraudulenta" de bienes como

32 Así, aceptando la apropiación indebida: Castro Moreno, El delito societario de administración desleal, 1998, pp. 318 ss.; Martínez-Buján, El delito societario de administración desleal, 2001, pp. 55-56; Rodríguez Montañés, Administración societaria fraudulenta, 2002, p. 285; STS 8984/2002, de 29-7 (Caso Banesto).

33 Así, aceptando la apropiación indebida, la doc. mayoritaria: Castro Moreno, El delito societario de administración desleal, 1998, pp. 318 ss.; Martínez-Buján, El delito societario de administración desleal, 2001, pp. 55-56; Rodríguez Montañés, Administración societaria fraudulenta, 2002, p. 285; STS 8984/2002, de 29-7 (Caso Banesto). No obstante, igual que en el supuesto 2, la doc. dom. aprecia concurso de leyes en vez de concurso ideal de delitos.

34 Cfr. más extensamente sobre lo que sigue Luzón/Roso, en Boix (dir.)/Lloria (coord.), Diccionario DP económico, 2008, pp. 48 ss.

35 Así p.ej. Nieto, El delito de administración fraudulenta, 1996, pp. 277 s., indicando au significado literal de engañoso o con abuso de confianza, pero también que de ese modo el requisito es superfluo, como sostiene una numerosa posición. 
aquella que defrauda legitimos intereses y expectativas con el consiguiente perjuicio para los mismos. Fraudulenta será por tanto en sentido objetivo la disposición de bienes sociales que es capaz de producir y produce (acción y efecto) un fraude, una defraudación de esos intereses, en el mismo sentido en que el CP utiliza el concepto en diversas figuras típicas, entre otras en las "defraudaciones" del Cap. VI del Tít. XIII (no sólo estafa, sino también apropiación indebida o defraudación de energías o similares) o en las conductas del Tít.XIV consistentes en "defraudar" a la Hacienda pública o a la Seguridad social.

Esta interpretación, que creemos que en cualquier caso ha de defenderse, no obsta a que además se le dé al término fraudulentamente también una carga subjetiva en el sentido de mala fe, como parece que es lo coherente con su significado: 'fraudulenta' es la actuación del administrador que no persigue el beneficio de la sociedad y los socios. La adicional connotación objetiva del término "fraudulentamente" supone que los intereses patrimoniales legítimos que se pueden ver defraudados con la disposición de bienes sociales pueden pertenecer en principio a varios sujetos: a la sociedad, a los socios o los otros equiparados en el art. 295.

\subsection{Contracción de obligaciones económicamente perjudiciales para socioso}

equiparados $^{36}$. La segunda de las alternativas típicas se describe como el contraer obligaciones perjudiciales a cargo de la sociedad. Estas conductas, que no implican siquiera disposición de bienes y derechos reales, sino sólo endeudamiento (excesivo y abusivo) de la sociedad, suponen un segundo ámbito de ampliación de la tipicidad en la administración desleal societaria respecto del delito de apropiación indebida. Al igual que en la disposición de bienes, el administrador contraerá obligaciones en nombre de la sociedad de un modo habitual y usual, y al representar a la sociedad y de cara a terceros el negocio será válido en principio aunque sea abusivo. Pero en la esfera interna estas obligaciones directamente perjudiciales para los socios o equiparados no son jurídicamente legítimas, desde el momento que no se respeta el deber de lealtad y se priman intereses de terceros o propios que conllevan un descalabro económico para la sociedad y los socios y similares.

Así p. ej. solicitar un préstamo aceptando innecesariamente unos intereses desmedidos, o arrendar para la sociedad unos locales de un tercero pactando abonarle una renta excesiva, o comprometer a la sociedad a abonar a directivos o empleados indemnizaciones por despido o jubilación abusivamente elevadas y gravosas.

36 Cfr. Luzón/Roso, en Boix (dir.)/Lloria (coord.), Diccionario DP económico, 2008, pp. 50 s. 
El tipo exige que la asunción de obligaciones a cargo de la sociedad sea "causando directamente un perjuicio económicamente evaluable a sus socios, depositarios, cuentapartícipes o titulares de los bienes, valores o capital que administren" [scil. los administradores]. Ya hemos visto (supra 2.1. a c'1 y 2.1.b 2) que esta exigencia afecta sólo a la contracción de obligaciones (a la que va directamente unida, sin una coma de separación tras "a cargo de ésta" que pudiera hacer pensar que el inciso siguiente se refiere a las dos modalidades anteriores unidas entre sí sin coma de separación), y no a los actos de disposición de bienes sociales, en los que basta que sean fraudulentos, perjudiciales, pero con perjuicio jurídico, aunque no sea directamente económico; mientras que en la contracción de obligaciones su menor repercusión jurídica (no modificación de la situación de cosas y derechos reales, como en la disposición de bienes, sino sólo surgimiento de derechos de crédito/obligaciones) se compensa exigiendo que cause directamente un perjuicio evaluable económicamente ( $\mathrm{v}$. infra $5 \mathrm{c}$ ) y además que afecte en todo caso a los socios o equiparados. Como veremos con más detalle (y con ejemplos en el apartado del sujeto pasivo o titular del bien jurídico: infra $3 \mathrm{~b}$ ), en esta modalidad de contraer obligaciones el patrimonio de estos últimos se protege por sí solo, o sea, aunque sólo se vea perjudicado el mismo y no el de la sociedad, mientras que el patrimonio social sólo se protege si es perjudicado simultáneamente con el de socios o asimilados, pero no por sí solo ${ }^{37}$.

2.3. Comisión omisiva. Se plantea la cuestión, relacionada ya con las dos actuaciones típicas descritas, de si cabe la comisión por omisión ${ }^{38}$ en este delito de resultado, englobando entonces actuaciones en las que el sujeto activo realiza una mala gestión que conlleva un perjuicio económicamente evaluable, cuando debido a su inactividad se produce una lesión o perjuicio económico para la sociedad o por su dejadez en la gestión la empresa o sociedad va acumulando pérdidas y deudas, o incluso si deja pasar ocasiones que hubieran redundado en un beneficio patrimonial para la sociedad.

Para poder orientar esta cuestión, teniendo en cuenta que la administración desleal societaria es un delito resultativo, que requiere en todo caso la causación

37 Desde la defensa de un concepto personal de patrimonio, pero sin identificar el patrimonio social con el patrimonio de los socios y asimilados, Mayo Calderón, La tutela de un bien jurídico colectivo, pp. 2005, 213 ss., 321 ss. y en particular 252-253, en donde defiende una posición cercana a la nuestra y afirma que: „cuando de la acción de administración fraudulenta se derive un perjuicio para el patrimonio de la sociedad pero no un perjuicio para socios y terceros únicamente podrá aplicarse el delito en grado de tentativa“. De modo totalmente diferente a nuestra posición, la mayoría de la doctrina parte de la identidad entre ambos patrimonios. así p.ej. Nieto Martín, El delito de administración fraudulenta, 1996, pp. 259 ss.; Rodríguez Montañés, La responsabilidad penal del administrador desleal, 1997, p. 125.

38 Sobre todo ello cfr. Luzón/Roso, en Boix (dir.)/Lloria (coord.), Diccionario DP económico, 2008, pp. 50 ss. 
de un resultado de perjuicio, son de aplicación las exigencias del art. $11 \mathrm{CP}$ : "los delitos o faltas que consistan en la producción de un resultado sólo se entenderán cometidos por omisión cuando la no evitación del mismo, al infringir un especial deber jurídico del autor, equivalga, según el sentido del texto de la Ley, a su causación". Por tanto, dado que el administrador social sí tiene por su cargo un deber específico de no producir perjuicios a la sociedad o a los socios (deber de garante), habrá que examinar si hay equivalencia entre la omisión y la causación activa: hay que fijar, por un lado, la atención en los verbos típicos: disponer y contraer obligaciones y, por otro lado, optar por un criterio de equivalencia entre la acción y la omisión ${ }^{39}$. Ambos verbos típicos (disponer de bienes, contraer obligaciones) tienen un claro contenido normativo y la cuestión depende de la interpretación que se sustente de ellos.

\section{Así si p. ej. disponer implica negocios jurídicos que extraigan de la esfera de dominio los bienes o que los sometan a gravámenes de garantía o a otros derechos reales o los sujeten a restricciones de uso por contratos como el arrendamiento o que dispongan definitivamente de los bienes sin despojo pero en condiciones}

39 En la doctrina española, la posición seguramente mayoritaria sostiene, a diferencia de lo que ocurre en la doctrina alemana (que sí admite la comisión omisiva para la modalidad de deslealtad y también, aunque con alguna posición en contra, para la modalidad del abuso: cfr. Martínez Pérez, EPCr, XVII, 1994, pp. 281 s.; Martínez-Buján, El delito societario de adm. desleal, 2001, p. 60 s.), que no cabe comisión por omisión, porque, aunque sí hay posición de garante, el deber específico del administrador, las conductas omisivas no equivalen a las modalidades típicas de disponer u obligar, además con abuso de la función, que son activas: así p.ej. Moreno Cánoves/Ruiz Marco, Delitos socioeconómicos, 1996, p.342; Faraldo, Los delitos societarios, 1996, p.581; Bajo, en Jornadas sobre DP económico, 1997, p.280; Fernández Teruelo, Los delitos societarios, 1998, pp. 336 s.; Mata Martín, CuadDJ 1998-5, pp.348 s.; González Cussac, en Vives/Orts/otros, 2004, p.619. Otra posición sostiene, como aquí, que excepcionalmente puede haber algunas conductas omisivas que materialmente equivalgan a las conductas típicas de disponer con salidas patrimoniales o de tener obligaciones perjudiciales: así Nieto, El delito de administración fraudulenta, 1996, pp. 118, 276 ss. (con un criterio muy restrictivo, admitiendo con razón el ej. de permitir el administrador por silencio la prórroga de un contrato que por cambio de circunstancias resulta muy desventajoso para la sociedad, rechazando supuestos como no realizar una conducta obligada para incrementar el patrimonio, no evitar la causación de un daño o permitir fallos en la producción); Castro Moreno, El delito societario de administración desleal, 1998 , pp.426 ss. (más amplio: admite no sólo el caso de no cumplir una obligación de la sociedad en plazo y provocar el deber de indemnización -que creemos que sí supone contraer obligaciones-, sino también el supuesto de un administrador encargado de vender unas acciones que a sabiendas no lo hace en su momento privando a la sociedad del beneficio, en el que es como mínimo muy dudoso que haya disposición de bienes -en el texto a continuación nos pronunciamos negativamente- $\mathrm{y}$ no hay asunción de obligaciones); Martínez-Buján, El delito societario de adm. desleal, 2001, p. 60-63 (que comparte el ejemplo de Nieto y no se opone a los de Castro); Mayo Calderón, La tutela de un bien jurídico colectivo, 2005, pp. 322 ss., especialmente 324 s., que, siguiendo el criterio de Gracia Martín de exigir para la equivalencia asunción de un compromiso de contener el riesgo y tener capacidad de realizar la acción de dominio de la causa fundamental del resultado, admite comisión por omisión en los casos del administrador que deja pasar la oportunidad de concluir un negocio con una sociedad para llevarlo a cabo con una sociedad vinculada a él, con lo que la sociedad que administra obtiene mucho menos beneficio, o el que no ejercita una acción contra una sociedad controlada por él y con ello causa la pérdida de importantes derechos económicos a la sociedad que administra; Luzón/Roso, en Boix (dir.)/Lloria (coord.), Diccionario DP económico, 2008, pp. 50-53, con los ejs. que se exponen en el texto. Parece inclinarse también por la comisión por omisión, a diferencia de su posición en 1996, Faraldo, Los delitos societarios, 2000, p.339. 
desventajosas, o si por el contrario por disponer se puede entender algo distinto como dilapidar no sacando el mayor beneficio y frutos a la cosa, con lo que se está realizando una mala disposición de los bienes, como sinónimo de gestión. La definición de lo que es disponer ha sido efectuada anteriormente, y se resuelve en el primer sentido y no en el segundo tan extensivo ${ }^{40}$ (v. supra 6.1. a b'); por ello en principio puede parecer que las conductas pasivas no equivalen a los actos de disposición de los bienes. Pero hay que hacer la salvedad de los casos excepcionales en que la pasividad del administrador tenga los mismos efectos que la disposición activa de bienes. Así cuando su omisión de denuncia, interrupción, etc., permita indebidamente a terceros adquirir la propiedad (por prescripción adquisitiva o usucapión) o adquirir o consolidar derechos reales, como servidumbres, a la vista, ciencia y paciencia del administrador, o que el arrendatario obtenga la prórroga automática de un arrendamiento de bienes de la sociedad al no denunciarlo el administrador pese a tener instrucciones de hacer concluir el contrato.

E igualmente hay que decidir si contraer obligaciones supone realizar actos o negocios jurídicos en los que la sociedad asuma el papel de deudora o si también se puede sostener que se contraen obligaciones cuando simplemente se deja subsistir una obligación, p.ej. si no se da la orden de cancelación del préstamo, teniendo la sociedad activo suficiente para hacerlo y el administrador, sólo con el propósito de endeudarla y perjudicarla, no se determina a realizar la cancelación del préstamo; en esta segunda hipótesis hay que negar la equivalencia, porque la omisión de la actuación no supone contraer nuevas obligaciones, sino sólo mantener las obligaciones ya existentes. Ahora bien, al igual que en la disposición de bienes, también aquí hay que hacer la excepción para los supuestos en que la omisión de actividades debidas por el administrador precisamente haga surgir obligaciones para la sociedad perjudiciales para los socios, como sucederá si, pudiendo pagar la deuda (p.ej. el préstamo), el administrador incurre conscientemente en mora o niega el cumplimiento, generando obligación de indemnizar ${ }^{41}$, o también en la omisión dolosa, no por mera negligencia, de deberes de control que terminen perjudicando patrimonialmente a la sociedad, p.ej. en la omisión consciente de precauciones o medidas de seguridad en una actividad peligrosa de la empresa, lo que provoca accidentes con la consiguiente obligación de indemnizar a las víctimas: empleados o terceros, o en una pésima

40 Por ello a nuestro juicio no hay disposición de bienes fraudulenta en el ejemplo de Castro (v. la nota anterior) de un administrador encargado de vender unas acciones que a sabiendas no lo hace en su momento privando a la sociedad del beneficio.

41 Este ejemplo, que ya se pone y se fundamenta en Luzón/Roso, en Boix (dir.)/Lloria (coord.), Diccionario DP económico, 2008, p. 52, coincide con el propuesto por Nieto, El delito de administración fraudulenta, 1996, pp. 276, 278 (v. supra n. 38). 
gestión de los riesgos laborales que termine implicando la sanción de la misma con una multa administrativa de miles de euros.

\section{El sujeto pasivo del delito es, por definición, el titular del bien jurídico afectado.}

a) Y como hemos visto que el bien jurídico es doble, supraindividual e individual, hay por ello al menos un doble sujeto pasivo, colectivo y personal ${ }^{42}$ : la comunidad o colectividad como titular del legítimo interés comunitario en la fiabilidad del correcto funcionamiento de las sociedades y del sistema societario como presupuesto indispensable del buen funcionamiento del sistema económico; y la persona (jurídica) o personas (físicas) titular o titulares del patrimonio(s) afectado(s).

b) En cuanto al bien jurídico individual, el patrimonio, la cuestión es si la decisión normativa del art. 295 ha sido proteger alternativamente o, por el contrario, conjuntamente el patrimonio social y el patrimonio individual de socios y equiparados ${ }^{43}$.

Fácticamente, puede haber actos de administración desleal que afecten alternativamente a uno o a otro patrimonio, es decir perjudiciales únicamente para el patrimonio social o únicamente para el patrimonio de socios o equiparados. Por una parte, puede haber operaciones en las que no se dañe el patrimonio social y sí el de los socios: así p. ej. en una ampliación de capital social en la que el patrimonio social salga favorecido pero no así el patrimonio individual de socios o de terceros equiparados, que tampoco han podido ejercitar su derecho de suscripción preferente de acciones, o que carecen de capacidad económica para hacerlo cuando la ampliación era objetivamente innecesaria, traduciéndose como poco en una pérdida en su porcentaje en el capital social. $\mathrm{O}$, por otra parte, puede darse el caso contrario, en el que se dañe el patrimonio social, sin perjudicar el de los socios: así pensemos en los supuestos de descapitalización de la sociedad en los que el administrador, por indicación de los socios, dispone de todos los bienes y valores a favor de otras empresas pertenecientes a estos mismos socios.

Normativamente cabe considerar que ambas clases de causación de perjuicio están desvaloradas y se consideran ilícitas (en general, sin entrar aún en si son penalmente típicas): Lo son las actuaciones fraudulentas perjudiciales sólo

Así Luzón/Roso, en Boix (dir.)/Lloria (coord.), Diccionario DP económico, 2008, p. 53.

Cfr. Luzón/Roso, en Boix (dir.)/Lloria (coord.), Diccionario DP económico, 2008, pp. 53 ss. 
para el patrimonio de socios o equiparados, porque ya en el Derecho privado se establece un deber de representación leal y de consiguiente responsabilidad del administrador no sólo frente a la sociedad sino también frente a los socios o accionistas (arts. 127 y 133 LSA, 61 y 69 LSRL). Y son igualmente desvalorados e ilícitos los actos fraudulentos en perjuicio sólo de la sociedad aunque no de los socios: En el ejemplo propuesto, el que el administrador de una sociedad anónima o limitada descapitalice indebidamente la sociedad (lo que supone disposición de sus bienes en favor de terceros), por mucho que sea por indicación de los socios y en beneficio de empresas de éstos, se considera un acto ilícito en Derecho mercantil, ya que, al perjudicar patrimonialmente a la sociedad, ello va a ser perjudicial también para los legítimos intereses de acreedores o empleados de la misma.

Ahora bien, la cuestión es si ambas clases de causación de perjuicio son no sólo extrapenalmente antijurídicas, sino también penalmente típicas, o sea, si en la regulación típica del art. $295 \mathrm{CP}$ ambos patrimonios, el de la sociedad y el de los socios o equiparados se protegen conjunta o alternativamente. Como hemos visto, la cuestión es distinta en cada una de las dos modalidades de conducta típica ${ }^{44}$ :

1) En la disposición fraudulenta de bienes se protege indistinta y alternativamente el patrimonio social o los individuales indicados (o también a ambos conjuntamente), dado que a esta modalidad no le afecta la exigencia típica de causar un perjuicio económico a socios o asimilados. Por ello el fraude, como recae sobre bienes de la sociedad, puede afectar aisladamente al patrimonio social, o alternativamente la disposición puede ser fraudulenta únicamente para los patrimonios de socios o equiparados, o por último el fraude, claro está, puede afectar conjuntamente al patrimonio social y a los individuales de socios y asimilados.

2) Pero en la asunción de obligaciones, dada la exigencia legal expresa de causación de perjuicio económico a los socios o equiparados, el patrimonio social sólo se protegerá conjuntamente con dichos patrimonios individuales, pero no por sí mismo, es decir cuando sólo se perjudique el patrimonio social, mientras que sí se protegen aisladamente

Frente a esta solución aquí defendida (similar Mayo Calderón, La tutela de un bien jurídico colectivo, 2005, pp. 252-253: v. supra n. 36), sostienen que en ambas modalidades típicas ha de verse afectado el patrimonio de la sociedad y el de terceros, p.ej. Nieto Martín, El delito de administración fraudulenta, 1996, pp. 259 ss.; Rodríguez Montañés, La responsabilidad penal del administrador desleal, 1997, p. 125. 
los intereses patrimoniales individuales de socios o asimilados, aunque no haya un perjuicio paralelo para el patrimonio social (ej. de la ampliación de capital social acordada innecesariamente, por existir otros medios para obtener recursos, para perjudicar a algunos socios, que no tendrán capacidad económica para suscribir tal ampliación).

No será típica en el caso contrario, ciertamente infrecuente, en el que la asunción de una obligación dañe sólo y exclusivamente el patrimonio social, pero no perjudique al patrimonio de ningún socio o equiparado: así si el administrador hace suscribir a una pequeña sociedad un contrato como arrendataria de unos locales de negocios teniendo que pagar una renta claramente excesiva, pero ese contrato es precisamente en favor de los tres únicos socios, que son a su vez propietarios de los locales arrendados.

c) Los sujetos equiparados a los socios: depositarios, cuentapartícipes o titulares de los bienes, valores o capital administrados ${ }^{45}$.

Todos ellos tienen intereses de una manera u otra en la sociedad; pero se plantea como dudosa la cuestión de si frente a ellos el administrador de hecho o de derecho tiene deberes de lealtad y fidelidad; si no los tuviera, sería criticable la equiparación. En principio, cabría pensar en una respuesta negativa, ya que el deber de lealtad y de fidelidad lo tienen los administradores con la sociedad y con los socios (cfr. arts. 127 ss., 133 LSA, 61 y 69 LSRL) y teniendo esto en cuenta, se podría argumentar que la enumeración legal de esos sujetos en el tipo penal no tiene por sí misma virtualidad para que el deber de fidelidad y lealtad, que tiene el administrador con la sociedad y los socios, se extienda a esos terceros $^{46}$.

Sin embargo, también cabe argumentar en sentido contrario, y parece más convincente, que los sujetos equiparados por el art. $295 \mathrm{CP}$ a los socios no son terceros cualesquiera, sino precisamente cuentapartícipes, depositarios o titulares de bienes, valores o capital que administren los administradores sociales y que por ello resultan directamente perjudicados económicamente por la contracción de obligaciones para la sociedad efectuada por el administrador, y que por tanto el administrador vulnera también frente a estos asimilados el deber de lealtad que el derecho civil y el mercantil le impone al administrador frente al administrado ${ }^{47}$.

45 Cfr. Luzón/Roso, en Boix (dir.)/Lloria (coord.), Diccionario DP económico, 2008, pp. 55 s.

46 Sobre esta cuestión cfr. Castro Moreno, El delito societario de administración desleal, 1998, pp. 398399; Faraldo Cabana, Los delitos societarios, 2000, p. 330; Mayo Calderón, La tutela de un bien jurídico colectivo, 2005, pp. 236 ss.

47 Así Luzón/Roso, en Boix (dir.)/Lloria (coord.), Diccionario DP económico, 2008, pp. 55 s. En el 
Es decir, que su equiparación legal como sujetos pasivos a los socios se basa en que sus bienes, valores o capital (o en el caso más importante de los depositarios mercantiles, las entidades financieras que reciben de clientes depósitos irregulares o depósitos administrados de valores, los valores o capital respecto de los cuales los depositarios actúan como mandatarios o representantes) son gestionados por la sociedad precisamente a través del administrador, que entonces está también defraudando los deberes de lealtad que imponen el Derecho civil y el mercantil al administrador respecto de los administrados (los titulares de los bienes o valores, sus equivalentes los depositarios de los mismos o los cuentapartícipes). Y en el caso de los cuentapartícipes, a ello se añade que los partícipes o aportantes en un contrato de cuentas en participación (arts. 239-243 CCom) para la gestión ocasional o duradera de intereses u operaciones, que funciona internamente como una sociedad pero sin constitución formal ni actuación como tal frente al exterior, son el equivalente material de los socios en las sociedades formalmente constituidas; por esta razón adicional el administrador tiene igualmente frente a los cuentapartícipes los mismos deberes de lealtad que frente a los socios, deberes que quebranta en caso de asunción de obligaciones con perjuicio económico para los mismos ${ }^{48}$.

d) Los intereses patrimoniales de terceros no equiparados a los socios ${ }^{49}$, fundamentalmente los acreedores o empleados de la sociedad quedan, pues, protegidos en la medida en que se protege a la sociedad frente a actos fraudulentos que, al perjudicar su patrimonio, redundan también en perjuicio del cumplimiento de sus obligaciones frente a terceros. Pero el art. 295 no protege por si mismo y de modo autónomo el patrimonio de los terceros no equiparados a los socios. Ello está claro en la segunda modalidad típica, la de contraer obligaciones a cargo de la sociedad, en donde sólo se menciona el perjuicio económico para los socios o equiparados, pero no para otros terceros. Ciertamente que en la primera modalidad típica, la de disponer fraudulentamente de bienes de la sociedad, cabría sostener que sí se protege el patrimonio de los terceros por sí mismo, ya que una de las formas de disponer "fraudulentamente" es hacerlo en fraude precisamente de legítimos intereses patrimoniales de terceros aunque el fraude no afecte al patrimonio social ni al de socios o asimilados. No obstante, teniendo en cuenta el argumento sistemático de que en este mismo Cap. XIII de los delitos societarios el art. 290 en las falsedades documentales societarias, -donde no se habla de abuso de funciones del cargo- sí se refiere a

mismo sentido Castro Moreno, El delito societario de administración desleal, 1998, 398-399; Faraldo Cabana, Los delitos societarios, 2000, 330.

48 Así Luzón/Roso, en Boix (dir.)/Lloria (coord.), Diccionario DP económico, 2008, p. 56.

49 Cfr. Luzón/Roso, en Boix (dir.)/Lloria (coord.), Diccionario DP económico, 2008, pp. 38 s. En sentido similar: Quintero Olivares/Morales Prats, Comentarios al Nuevo CP, 3. a , 2004, S. 1469. 
la idoneidad para causar perjuicio no sólo a la sociedad o a cualquier socio, sino también expresamente: "o a un tercero", mientras que el art. 295 no lo menciona expresamente en ninguna de sus dos modalidades de acción típica, sino que alude en la primera a la sociedad y en la segunda a los socios o equiparados, parece más acorde con esa diferente redacción de ambos preceptos una interpretación restrictiva de la modalidad "disposición fraudulenta", entendiendo que no basta con un fraude exclusivamente para terceros si no hay perjuicio para la sociedad o los socios o equiparados; interpretación que es además coherente con lo que rige en la segunda modalidad típica de contracción de obligaciones. Esta interpretación es por otra parte obligada a la vista de la exigencia típica en el 295 de abuso de las funciones propias del cargo, cuyo telos es precisamente sancionar la administración infringiendo los deberes de lealtad del administrador, que se refieren a la sociedad y los socios o equiparados, pero no a terceros. Por consiguiente, hay que entender que para la protección del patrimonio de terceros ajenos a la sociedad (acreedores, empleados) frente a fraudes a los mismos, el CP considera ya suficiente la existencia de otros tipos como p.ej. la estafa u otros fraudes, el alzamiento de bienes, los concursos punibles, o los delitos contra la Hacienda pública o la Seguridad social.

\section{Abuso de funciones propias del cargo (infracción de deberes de lealtad) ${ }^{50}$.}

Este elemento recoge y plasma esencialmente (aunque, como ya vimos, también podemos encontrar esta idea generalmente -no siempre-implícita en el adjetivo 'fraudulento' que acompaña a la disposición) el incumplimiento de los deberes de fidelidad y de lealtad. Los deberes de lealtad que resultan jurídico-penalmente relevantes para constituir una infracción no son todos los deberes de lealtad y buena fe definidos por el Derecho mercantil o el civil, sino los más importantes (por ser más graves las repercusiones de su infracción) y de contenido material: son los deberes de lealtad y fidelidad en la administración y representación que hemos visto (supra III 3 b) que tiene el administrador social frente a la sociedad y los socios o accionistas (arts. 127 y 133 LSA, 61 y 69 LSRL). En cambio, no hay específicos deberes de lealtad del administrador social con los terceros, pero sí una protección más amplia de éstos en el Derecho mercantil:

Se discute si se debe considerar o no abuso del cargo aquellas actuaciones llevadas a cabo fuera del ámbito de competencias del cargo. Para algunos autores el elemento del ejercicio del cargo lleva implícito que el administrador actúe dentro del ámbito de competencias que le han sido atribuidas y, si no actúa dentro de ese ámbito de competencias, no se puede decir que hay abuso de

50 Cfr. Luzón/Roso, en Boix (dir.)/Lloria (coord.), Diccionario DP económico, 2008, pp. 56 ss. 
funciones ${ }^{51}$. Pero parece más correcto interpretar que hay abuso de funciones tanto si el administrador actúa dentro de sus competencias pero de modo desleal, perjudicial, como si no lo hace y se extralimita ${ }^{52}$. Lo que importa es que se ha valido de su cargo y de la confianza depositada en él para realizar negocios jurídicos contrarios a los intereses que debía representar, generando una apariencia de regularidad y legalidad frente a terceros. Si no fuera así, quedarían fuera del ámbito del delito supuestos tan sangrantes y obvios como los del administrador que, no estando habilitado para vender bienes de la sociedad p. ej. títulos valores de la sociedad, lo hiciese.

Otro supuesto controvertido lo constituyen los negocios de riesgo y su supuesta subsunción en el delito de administración desleal. Como entiende la doc. mayoritaria ${ }^{53}$, estos casos deben solucionarse dentro del ámbito de interpretación del abuso de funciones y por ello el negocio de riesgo no supondrá una administración desleal si entra dentro de las atribuciones definidas y descritas del cargo; distinto sería si el negocio de riesgo se ha llevado a cabo sin sujetarse a los deberes de lealtad y fidelidad. En definitiva, dependerá de cómo se haya estructurado la relación interna entre el administrador y el administrado y del consentimiento de éste a dichas operaciones, consentimiento que puede constituir en estos casos una causa de atipicidad por irrelevancia jurídica general: materialmente por ausencia de lesión del bien jurídico en este caso, y formalmente porque con tal consentimiento de la sociedad administrada no se dará el requisito típico del abuso de las funciones del cargo.

Por otra parte, cuando el administrador asuma un negocio de riesgo, no habrá delito si no sobrepasa los límites del riesgo permitido, p.ej. en operaciones bursátiles, por mucho que naturalísticamente hubiera en él dolo eventual de producir perjuicio; en general se discute si el riesgo permitido excluye la tipicidad por falta de imputación objetiva o por adecuación social o excluye la antijuridicidad, pero aquí cabe entender que faltará la tipicidad por no obrar el administrador en tal caso con abuso del cargo ${ }^{54}$.

51 Una parte de la doctrina considera que con la introducción de este elemento en la definición típica se cuestionan los criterios de autoría en este tipo y su caracterización como delito de dominio o de infracción de un deber: cfr. en este sentido, Martínez-Buján, El delito societario de administración desleal, 2001, pp. 64-65. Otro sector se basa en la extralimitación de competencias y en los deberes ad intra y ad extra para distinguir entre apropiación indebida y administración desleal: así Gómez-Jara, La administración desleal de los órganos societarios, 2008, pp. 189 ss.

52 Así Mayo Calderón, La tutela de un bien jurídico colectivo, 2005, p. 271.

53 Cfr. Faraldo Cabana, Los delitos societarios, 1996, p. 535.

54 Sobre otras causas de exclusión de la tipicidad y de justificación en este delito cfr. Luzón/Roso, en Boix (dir.)/Lloria (coord.), Diccionario DP económico, 2008, pp. 62 s. 
5. Resultado de perjuicio ${ }^{55}$. Este delito es un delito de resultado, ya que exige en todo caso la producción de un perjuicio patrimonial que, como hemos anticipado, afectará a la sociedad o a los socios o equiparados. El perjuicio va contenido ya implícitamente en el propio término "fraudulentamente" de la primera modalidad típica, la disposición fraudulenta de bienes, y se requiere explícitamente en la otra modalidad típica de contracción de obligaciones.

Ya se ha dicho, sin embargo, que no se comparte la extendida opinión de que se requiere para todas las modalidades de conducta típica la producción no sólo de un perjuicio, sino en causación directa, y de perjuicio económicamente evaluable y además a los socios o asimilados, se requiere para todas las modalidades de conducta típica ${ }^{56}$ (v. supra III. 2.1 a c'1).

a) Como delito de resultado es necesario que exista una relación de causalidad constatada entre la producción del perjuicio y la acción típica (de disposición o de asunción de obligaciones). Pero además es necesario constatar la imputación objetiva; por tanto, hay que constatar que el acto de disposición de bienes o de contracción de obligaciones es adecuado, crea un riesgo jurídicamente relevante de causar un perjuicio patrimonial y que tal perjuicio supone precisamente la realización del riesgo o peligro y encaja en el fin de protección de la norma típica.

b) En la primera modalidad de acción típica, la disposición fraudulenta de bienes de la sociedad, el término "fraudulentamente", como hemos visto, implica que cause perjuicio patrimonial o bien a la propia sociedad o a los socios y equiparados (a éstos hay que incluirlos también aquí por coherencia sistemática con la segunda modalidad de conducta típica) o a ambos conjuntamente; y no basta, en cambio, el perjuicio aislado a otros terceros, p.ej. acreedores o empleados, si no va unido al perjuicio para la sociedad o los socios. Pero tal perjuicio, además de económico, también puede ser puede ser puramente jurídico, incluso perjuicio moral, aunque no tenga directamente una repercusión y valoración económica (indirectamente la acabará teniendo; recuérdese el ejemplo (supra en 2.1. a c'1) de la venta por el administrador a precio correcto o ventajoso pero no autorizada por la sociedad: aun habiendo obtenido un buen precio, si el vendedor muestra su interés en re-comprar, ello producirá normalmente un aumento y encarecimiento para el precio de la nueva compra, por

55 Cfr. Luzón/Roso, en Boix (dir.)/Lloria (coord.), Diccionario DP económico, 2008, pp. 58 ss.

56 Cfr. doc. cit. supra n. 28. 
tanto indirectamente acaba produciendo un perjuicio económico a la sociedad y los socios).

c) En la segunda modalidad de conducta típica, la de contraer obligaciones a cargo de la sociedad, se exige una causación directa de un perjuicio económicamente evaluable. Además la causación debe ser produciendo directamente tal perjuicio económico a sus socios, depositarios, cuentapartícipes o titulares de los bienes, valores o capital que administren.

Sobre la exigencia de causación "directa"se han dado muy diversas interpretaciones. De ellas no resultan convincentes la de que 'directamente' refleja la necesidad de imputación objetiva entre acción y perjuicio ${ }^{57}$, o la de que ese término excluye aquellas operaciones que han supuesto finalmente un perjuicio, pero que se encuadran dentro de un riesgo normal y socialmente adecuado ${ }^{58}$, o la que sostiene que 'directamente' supone la necesidad de que el perjuicio se traduzca en una pérdida inmediata en la cuenta de resultados, pero no incluye el lucro cesante, recurriendo para el caso a la responsabilidad civil ${ }^{59}$.

La interpretación de 'directamente' está relacionada, por una parte con la repercusión económica de la conducta y, por otra, con la definición de sujeto pasivo en este delito. Así se exige, primero, que el perjuicio irrogado (a socios y equiparados) sea directamente evaluable económicamente y no simplemente un perjuicio jurídico (incluyendo el perjuicio moral), que luego indirectamente tenga repercusión económica.

En cuanto al sujeto pasivo, ya hemos visto (detalladamente supra III 3. b) que, a diferencia de la modalidad de disposición de bienes sociales, de las tres posibilidades conceptuales de sujeto perjudicado: sólo la sociedad, sólo los socios o asimilados o ambos conjuntamente, para la modalidad de contraer obligaciones la ley con el uso del adverbio "directamente" ha querido dejar claro que el patrimonio individual de -todos o algunos- socios o asimilados en cualquier caso debe quedar siempre perjudicado como tal, no sólo como repercusión muy indirecta y remota del perjuicio social, para que la conducta sea típica. Y aunque en la mayoría de los casos sea el patrimonio social el que sufra el perjuicio, éste resultará atípico, si al mismo tiempo no se perjudica claramente el patrimonio de al menos algunos socios, depositarios, cuentapartícipes o de otros titulares

Mayo Calderón, La tutela de un bien jurídico colectivo, 2005, pp. 249-250.

58 Nieto Martín, El delito de administración fraudulenta, 1996, pp. 281-282.

59 En contra: Faraldo Cabana, Los delitos societarios, 1996, p. 579. 
de los bienes administrados, ya que la sociedad no está en esa lista y el tipo no parece conformarse con el solo perjuicio al patrimonio social. Ciertamente, hay que reconocer que serán absolutamente excepcionales los supuestos en que haya claro perjuicio económico para la sociedad y no lo haya para ninguno de los socios o equiparados, que p. ej. resulten todos beneficiados por una operación de endeudamiento social abusivo. Y por otra parte, en tales casos excepcionales el desvalor de la conducta es mucho menor o incluso podría estar excluido desde el punto de vista societario por el consentimiento expreso, tácito o presunto, del órgano de representación social; y el aspecto lesivo que ese perjuicio para la sociedad puede producir a los legítimos intereses de terceros-empleados o acreedores- ya se tiene en cuenta en los delitos de insolvencias punibles.

\section{Parte subjetiva del tipo}

1. En la parte subjetiva del tipo, en primer lugar se requiere dolo, por tanto conocimiento y voluntad de realizar todos los elementos objetivos del tipo, y no está tipificada la comisión imprudente. Cabe el dolo eventual ${ }^{60}$, que es compatible con la actuación fraudulenta en la disposición de bienes, y como vamos a ver a continuación, con la actuación en beneficio propio o ajeno ${ }^{61}$.

2. Elemento subjetivo del tipo o del injusto: en beneficio propio o ajeno. Por último quedaría un elemento dentro de la descripción típica, que exige que el administrador o socio realice la conducta "en beneficio propio o de un tercero".

Aunque podría interpretarse tal requisito en sentido objetivo, como equivalente a "con beneficio", es decir exigiendo la producción de un segundo resultado además del de perjuicio, la mayoría de la doctrina considera ${ }^{62}$ con razón que nos encontramos ante un específico elemento subjetivo del injusto o del tipo que hay que añadir al dolo y que permite calificar al tipo de administración desleal como un delito cortado de resultado. Este elemento subjetivo, paralelo al ánimo de lucro o enriquecimiento propio o ajeno de otros delitos patrimoniales, pero algo más amplio -ya que admite otros beneficios que no impliquen estrictamente enriquecimiento, v.gr. obtener una posición de poder- es compatible con el dolo eventual. Y el delito estará consumado sin necesidad de que se haya producido un efectivo beneficio propio o de tercero, basta con que el sujeto tienda con su actuación a obtener tal beneficio; esto sucederá en la gran mayoría de los casos,

60 Por todos, Mayo Calderón, La tutela de un bien jurídico colectivo, 2005, pp. 354-355.

61 Así Luzón/Roso, en Boix (dir.)/Lloria (coord.), Diccionario DP económico, 2008, p. 61.

62 Nieto Martín, El delito de administración fraudulenta, 1996, pp. 286-287, 324; Faraldo Cabana, Los delitos societarios, 1996, 1996, pp. 155-156; Mayo Calderón, La tutela de un bien jurídico colectivo, 2005, pp. 345; Luzón/Roso, en Boix (dir.)/Lloria (coord.), Diccionario DP económico, 2008, pp. 61 s. 
pero tal elemento subjetivo específico hace que resulten atípicos los escasos supuestos en que el administrador actúe únicamente con voluntad de perjudicar a la sociedad o a los socios o equiparados.

\section{Causas de exclusión de la tipicidad y de justificación ${ }^{63}$.}

Pueden concurrir causas de atipicidad Por una parte causas de exclusión de entrada del tipo indiciario de cualquier injusto por falta de toda relevancia jurídica: Podría plantearse como tal el consentimiento del órgano social o de los socios cuando la operación no sea perjudicial ni para la sociedad ni para los socios o equiparados, ya que materialmente faltará ya la lesión del bien jurídico (patrimonial, pero también el supraindividual). No obstante, realmente no hace falta recurrir al consentimiento como causa de atipicidad, pues a tal conducta le faltan ya los requisitos típicos del perjuicio y del abuso de funciones del cargo; en cambio, recuérdese que no es válido el consentimiento de los socios en una disposición de bienes -descapitalización- que redunda en perjuicio de la sociedad y de terceros (cfr. supra II 2 c; III 3 b) . La adecuación social de una operación será causa de exclusión ya del tipo indiciario de cualquier injusto si es también jurídicamente adecuada; si no coincide la adecuación social con la jurídica, será sólo causa de exclusión de la tipicidad penal. En cuanto al riesgo permitido hay discusión sobre si es siempre socialmente adecuado y por esa razón o por no haber imputación objetiva excluye la tipicidad, o si es más bien una causa de justificación o de exclusión de la antijuridicidad; pero en este art. 295 ocurre que si hay riesgo permitido, la conducta es atípica por no obrar el administrador con abuso de las funciones de su cargo.

Por otra parte, habrá exclusión sólo de la tipicidad penal (pero no de la responsabilidad extrapenal: civil o mercantil para el administrador), en virtud del principio de insignificancia, en la causación de perjuicios mínimos, bagatelas, si hay un mínimo desvalor del resultado y de la acción, como en una disposición fraudulenta de bienes de escaso importe (p.ej., $50 €$ ) y sin que el administrador pretenda causar una defraudación mayor, acto que sin embargo puede ser típico desde otra perspectiva: como falta de apropiación indebida inferior a $400 €$. Lo mismo ocurrirá si en alguna operación cabe apreciar la circunstancia de tolerancia social.

63 Sobre ello cfr. en la administración desleal Luzón/Roso, en Boix (dir.)/Lloria (coord.), Diccionario DP económico, 2008, pp. 62 s. En general, Luzón Peña, Causas de atipicidad y causas de justificación, en Luzón/Mir (eds.), Causas de justificación y de atipicidad en DP, 1995, pp. 21 ss.; Curso DP, PG I, 1996, pp. 555 ss.; Causas de atipicidad, en Luzón Peña (dir.), EPB, 2002, pp. 237 ss.; Causas de atipicidad, en: Valdágua (coord.), Problemas fundamentais de Direito Penal. Colóquio Internacional de Direito Penal em homenagem a Claus Roxin, Lisboa, Univ. Lusíada, 2002, pp. 109 ss. 
En cuanto a causas de justificación, aparte de la eventual aplicación excepcional de un estado de necesidad, será aplicable sobre todo el ejercicio legítimo de un derecho y del cargo según las normas de otros campos jurídicos, fundamentalmente del Derecho civil y del mercantil, y en particular lo que quepa desprender de sus regulaciones y principios generales para el riesgo permitido en negocios de riesgo: nos remitimos a lo expuesto (supra III.4) al tratar el requisito de obrar con abuso de las funciones propias del cargo de administrador; pero hay que insistir en que, si la conducta no supone abuso de las funciones propias del cargo de administrador, no sólo está justificada sino que es ya directamente atípica al faltar ese elemento de la descripción legal.

\section{Iter criminis}

En el iter criminis ${ }^{64}$ resumidamente cabe destacar: A diferencia de la apropiación indebida, en la que según el art. 269 son punibles, no lo son por no estar expresamente tipificados los actos preparatorios de conspiración, proposición y provocación para la administración desleal (salvo en los casos de disposición fraudulenta que al mismo tiempo constituyan apropiación indebida). Al ser un delito de resultado, cabe no sólo la tentativa inacabada, sino también la tentativa acabada ${ }^{65}$ cuando no se produzca el perjuicio (para la sociedad o para socios y asimilados, en la forma descrita) requerido por el tipo. En cuanto se produzca el perjuicio, hay consumación, y es irrelevante (salvo para la determinación concreta de la cuantía de pena y para la responsabilidad civil cuando proceda restitución y reparación del daño) si además se obtiene o no el beneficio propio o de tercero perseguido por el autor, lo que pertenece únicamente a la fase de terminación o agotamiento.

\section{Autoría y participación}

En cuanto a formas de intervención en el delito ${ }^{66}$, dado que estamos ante un delito especial propio -ya que en el actual art. 295 el sujeto activo es sólo el administrador societario y no existe una figura paralela realizada por el administrador de un particular, ni menos por un sujeto cualquiera no administrador-, los extranei no administradores no pueden ser nunca autores del delito, ni autores directos individuales ni autores mediatos ni coautores, salvo que se les pueda aplicar la

64 Cfr. Luzón/Roso, en Boix (dir.)/Lloria (coord.), Diccionario DP económico, 2008, p. 63.

65 Así Martínez-Buján, El delito societario de administración desleal, 2001, p. 77.

66 Cfr. Luzón/Roso, en Boix (dir.)/Lloria (coord.), Diccionario DP económico, 2008, pp. 63 s. En general sobre autoría y participación cfr. Díaz y García Conlledo, La autoría en Derecho Penal, 1991; también sus artículos: Autoría; Autoría mediata, coautoría y autoría accesoria; Cooperación necesaria y complicidad; Participación, todos en Luzón (dir.), EPB, 2002, pp. 139 ss., 161 ss., 311 ss.; 977 ss. 
forma de ampliación de la autoría del art.31 por actuar en nombre o representación de otro (del administrador, o de la propia sociedad aun sin ser administradores), de modo que en los restantes casos, aunque los extraños realicen actos típicos, sus conductas deberán ser reconducidas a la participación, que sí es punible:

No sólo en estos casos, sino en general, cabe la participación -inducción, cooperación necesaria y complicidad- del extraneus (aquí el no administrador) en el delito especial, como reconoce la doctrina y jurisprudencia dominantes ${ }^{67} \mathrm{y}$ lo confirma la propia ley, el art.65.3 CP, que prevé en tal caso la posibilidad de atenuación cualificada de la pena al inductor o cooperador necesario extraneus. Para el cómplice extraneus -que no es mencionado en el art. 65.3- cabe la aplicación normal de la atenuante analógica de sujeto no cualificado, como admite un sector doctrinal y la jurisprudencia moderna ${ }^{68}$.

\section{Concurso y delimitación con otros delitos}

1. Hay que delimitar la administración desleal de otras figuras con las que guarda una cierta afinidad ${ }^{69}$.

La tarea de delimitación cobra la mayor importancia frente a otra figura delictiva como es la apropiación indebida, sobre todo cuando se ha interpretado por parte de la jurisprudencia y de la doctrina que la apropiación indebida recoge un tipo de administración desleal en el verbo típico 'distraer' y cuando el objeto del delito es el de dinero. La consecuencia principal de esta delimitación se encuentra en la resolución del concurso cuando ante un hecho real coinciden las características de ambas figuras delictivas. Sobre la apreciación de concurso, la mayoría de la doctrina y jurisprudencia española considera que hay entre ambas figuras concurso de leyes, que se resuelve para unos por la relación de especialidad a favor de la administración desleal ${ }^{70}$ pese a que generalmente es el

67 Sobre el tema en la administración desleal cfr. Mayo Calderón, La tutela de un bien jurídico colectivo, 2005, p. 327. En general cfr. Gómez Martín, Los delitos especiales, 2006, pp. 395 ss.; Peñaranda, LHGimbernat, 2008, pp. 1419 ss.; Olaizola, en Sánchez Ostiz (coord.), 50 casos, 2010.

68 Cfr. Gómez Martín, en LH-Cobo, 2005,pp. 455 s.; Los delitos especiales, 2006,pp. 544 ss.; Peñaranda, LH-Gimbernat, 2008, pp. 1419 ss.; Olaizola, en Sánchez Ostiz (coord.), 50 casos, 2010. A favor de la doble atencuación para el cómplice/extraneus también la Circular 2/2004 de la Fiscalía General del Estado.

69 Cfr. más extensamente Luzón/Roso, en Boix (dir.)/Lloria (coord.), Diccionario DP económico, 2008, pp. $64 \mathrm{~s}$.

70 Bacigalupo, en: AaVv, La administración desleal, 1999, pp. 193 ss.; Rodríguez Ramos, in: AaVv, La administración desleal, 1999, pp. 33 ss.; López Barja de Quiroga, en AaVv, DP económico, 2001, p. 484, aplica el principio de especialidad, pero considera que la ley especial es el art. 252 frente al 295; en el mismo sentido, Silva Castaño, en Bacigalupo (dir.), Curso de Derecho penal económico, $2 .^{\text {a }}$ 2005, p. 380. Rechazan expresamente el principio de especialidad y aplican el de alternatividad STS 9272/2000, 15-12, que aplica el principio de alternatividad; similar STS 8984/2002, 29-7 (caso 
tipo más benigno, mientras que para otros se soluciona en virtud de la relación de subsidiariedad, consunción o alternatividad a favor del tipo más grave, que generalmente es la apropiación indebida ${ }^{71}$.

Por el contrario, en nuestro trabajo conjunto "Concurso entre apropiación indebida y administración desleal" ${ }^{72}$, sostenemos que, dadas las diferencias entre el delito de apropiación indebida y el de administración desleal, que van desde la protección de distintos bienes jurídicos hasta distinto desvalor de acción y distinto desvalor del resultado, en tales supuestos no hay concurso de leyes, sino de delitos, generalmente (al haber una sola acción) concurso ideal del art. 295 con el art. 252 cuando la disposición fraudulenta de bienes de la sociedad consista precisamente en una apropiación definitiva o en distracción de dinero o efectos, es decir en una apropiación indebida superior a $400 €$; y en otras ocasiones de concurso real de ambos tipos delictivos mediante conductas distintas y separadas.

\section{Al estar ante un tipo mixto en el art.295, en caso de que un administrador social} realice simultáneamente una disposición fraudulenta de bienes y una contracción de obligaciones por la sociedad perjudicial para sus socios o asimilados, según las circunstancias del supuesto concreto y si ambas operaciones perjudiciales tienen o no entre sí una clara vinculación instrumental o de significado económicojurídico, podrá tratarse de un tipo mixto alternativo, con un único delito, o, por el contrario, cumulativo, con concurso de dos delitos ${ }^{73}$.

\section{Penalidad y perseguibilidad}

1. La pena que impone el art. 295 es de prisión de seis meses a cuatro años, o multa del tanto al triplo del beneficio obtenido. Esta pena, por diversas razones,

\section{Banesto).}

71 A favor de la subsidiariedad Rodríguez Montañés, La responsabilidad penal del administrador desleal, 1997, p.130; Martínez-Buján, El delito societario de administración desleal,2001, pp. 112 ss.; aprecia consunción Martínez-Buján, DP económico, PE, 1999, pp. 285 s.; El delito societario adm. desleal, 2001, p. 114. Defienden la alternatividad: Valle Muñiz, en Quintero (dir.)/Morales (coord.), Comentarios PE, 1. ${ }^{\mathrm{a}}$ ed., 1999, p. 724; Quintero/Morales, en Quintero (dir.)/Morales (coord.), Comentarios PE, 8. ${ }^{a}$ ed. 2009, p. 926; STS 224/1998, 26-2 (caso Argentia Trust); siguiéndola y desarrollándola STS 9272/2000, 15-12, rechazando además la especialidad; similar STS 8984/2002, 29-7 (caso Banesto), que admite la alternatividad, pero prefiere más bien (FJ 28) considerar la relación de ambos delitos como círculos tangentes más que como secantes.

72 Luzón/Roso, en Boix (dir.)/Lloria (coord.), Diccionario DP Económico, 2008, pp. 181 ss., 194 ss. En un sentido similar, Mayo Calderón, La tutela de un bien jurídico colectivo, 2005, pp. 275 ss., 374 ss. Y recientemente Gómez-Jara, La administración desleal de los órganos societarios, 2008, p. 194, n.69, p. 199.

73 Cfr. Luzón/Roso, en Boix (dir.)/Lloria (coord.), Diccionario DP económico, 2008, p. 65. 
es inferior a la de la apropiación indebida ${ }^{74}$. No obstante, desde la posición mayoritaria que opta por el concurso de leyes, esa menor pena del art. 295 frente al art. 252 ha propiciado que se busquen argumentos para aplicar más este delito de apropiación indebida al mayor número de casos dentro del ámbito societario. Se echa de menos una pena que tendría mucha eficacia en estos casos como es la inhabilitación especial para el ejercicio de industria y comercio.

2. En la administración desleal, al igual que los restantes delitos societarios, estamos ante un delito semi-privado con excepciones, ya que en el actual CP el art. 296 en su ap. 1 dispone que sólo es perseguible mediante denuncia de la persona agraviada -aquí, según los casos que hemos visto, la sociedad o los socios, depositarios, cuentaparticipes o titulares de los bienes, valores o capital administrados-. o de su representante (que tendrá que ser otra persona distinta del administrador delincuente), salvo que pueda denunciar también el Fiscal si el agraviado es menor, incapaz o persona desvalida. Aunque el ap. 2 dispone que "no será precisa la denuncia exigida en el apartado anterior cuando la comisión del delito afecte a los intereses generales o a una pluralidad de personas"; lo cual podrá suceder con frecuencia en la administración desleal societaria si son muchos los socios o equiparados perjudicados o si se trata de una sociedad importante en el tráfico económico.

\section{Lista de Referencias}

Aa Vv, El nuevo Código Penal. Delitos societarios e insolvencias punibles, Madrid, Banco Central Hispano 1996.

$\mathrm{AAVv}_{\mathrm{V}}$ El nuevo CP y los delitos societarios, Fundación Caixa Galicia, 1998.

Bacigalupo, E., La problemática de la administración desleal en el Derecho penal español, en: LH-Tiedemann ( $\mathrm{AAVv}$, Hacia un Derecho penal económico europeo. Jornadas en honor a Tiedemann), Madrid, BOE, 1995, pp. 385-400.

Los delitos societarios en el nuevo Código Penal, en: Bacigalupo Zapater, (dir.), Curso de Derecho penal económico, Madrid, M. Pons, 1998, pp. 129-144; La administración desleal en el nuevo Código Penal, en: CuadDJ 1999-7 (La administración desleal, dir. E. Bacigalupo), pp. 193 ss.; y en CPC 1999, pp. 521 ss.

Bacigalupo, E. (dir.), La administración desleal, CuadDJ 1999-7.

Bacigalupo Saggesse, S., Algunas cuestiones de participación en el delito fiscal y en el delito de administración desleal, RDPCr, extraord. 1, 2000, pp. 353 ss.

Bajo Fernández, Los delitos societarios en el nuevo Código Penal español, en : AAVv, Jornadas sobre Derecho Penal económico. La actividad empresarial desde la

74 Cfr. más ampliamente sobre las razones de esa distinta penalidad de ambos delitos Luzón/Roso, Concurso entre apropiación indebida y administración desleal, en Boix (dir.)/Lloria (coord.), Diccionario DP Económico, 2008, pp. 181 ss. 
perspectiva del nuevo Código Penal español, Oviedo, Univ. Oviedo/ Federación Asturiana de Empresarios, 1997, pp. 259 ss.

Bajo Fernández/Bacigalupo Saggesse, Derecho penal económico, Madrid, C. E. Ramón Areces, 2001; Brammsen, Strafbare Untreue des Geschäftsführers be einverständlicher Schmälerung des GmbH-Vermögens?, DB 1989, pp. 1609 ss.

Bufete Ramón Hermosilla, Los delitos societarios en el CP de 1995, Madrid, McGraw Hill, 1996; Castro Moreno, El delito societario de administración desleal (art. 295), Madrid, M. Pons, 1998.

Díaz Echegaray, La responsabilidad penal de los socios y administradores, Madrid, Montecorvo, 1997.

Díaz y García Conlledo, La autoría en Derecho Penal, Barcelona, PPU, 1991; Autoría, en Luzón Peña (dir.), EPB (Enciclopedia Penal Básica), 2002, pp. 139 ss.; Autoría mediata, coautoría y autoría accesoria, in Luzón (dir.), EPB, 2002, pp. 161 ss.; Cooperación necesaria y complicidad, en Luzón (dir.), EPB, 2002, pp. 311 ss.; Participación, en Luzón (dir.), EPB, 2002, pp. 977 ss.;

Díaz-Maroto Villarejo, Los delitos societarios en la reforma penal proyectada, en: LHTiedemann, Madrid, BOE, 1995, pp. 151-165; Las condiciones objetivas de perseguibilidad en los delitos societarios: el art. 296 del CP, LL 2000-7, pp. 1310-1315.

Díaz-Maroto y Villarejo/Polo Vereda, Problemas generales de aplicación de los delitos societarios Madrid, Ed. univ. Ramón Areces, 2004.

Eiranova Encinas, La responsabilidad penal en el ámbito de las sociedades mercantiles, Madrid, Montecorvo, 1998.

Faraldo Cabana, Los delitos societarios, Valencia, Tirant lo Blanch, 1996; Rasgos comunes a todos los delitos societarios, en $\mathrm{AAVv}, \mathrm{El}$ nuevo $\mathrm{CP}$ y los delitos societarios, Fundación Caixa Galicia, 1998, pp. 49 ss.; Los delitos societarios. Aspectos dogmáticos y jurisprudenciales, 2. ${ }^{\text {a }}$ ed., Valencia, Tirant lo Blanch, 2000; Acuerdos e la Junta general de socios de la sociedad limitada en asuntos de gestión y responsabilidad de los administradores, RDS 18, 2002, pp. 217 ss. Fernández Bautista, Aproximación al delito de administración fraudulenta (art. 295 $\mathrm{CP}$ ), en: Corcoy Bidasolo (dir.)/Lara González (coord.), Derecho penal de la empresa, Navarra, Aranzadi, 2002, pp. 107-129.

Fernández Teruelo, Los delitos societarios en el Código penal español, Madrid, Dykinson, 1998,pp. 309 ss.; El caso del Banco Español de Crédito: un "banco de pruebas" para la determinación del sentido de los delitos societarios, LL 20005, pp. 1675 ss.; Ferré Olivé, Sujetos responsables en los delitos societarios, RP 1, 1997, pp. 21 ss.; La administración fraudulenta (art. 295 del CP), en Galán/García-Cruces (coords.), La responsabilidad de los administradores de las sociedades de capital. Aspectos civiles, penales y fiscales, Madrid, Tecnos, 1999 , pp. 128 ss.

Foffani, Infedeltà patrimoniale e conflitto d'interessi nella gestione d'impresa (profili penalistici), Milano, Giuffrè, 1997; I reati societari nel nuovo codice penale 
spagnolo del 1995, in Rivista trimestrale di diritto penale commerciale, 1999, 1-2, pp. 65-89.

Foffani/Nieto Martín, Corporate Governance y administración desleal: casos y problemas de Derecho comparado europeo, en RP 17, 2006, pp. 110-141.

García Arán, Consideraciones sobre los delitos societarios en el nuevo Código penal, Economist \& Jurist 17 (1996), pp. 105 ss.; García Cavero, La responsabilidad penal del administrador de hecho de la empresa: criterios de imputación, Barcelona, J.M. Bosch, 1999; Otra vez sobre la responsabilidad penal del administrador de hecho: una cuestión general y otra particular (Responsables), en: Indret 3, 2006; GARcía-Cruces, El concepto de sociedad en la tipificación de los delitos societarios, AJA 389, 1999, pp. 1 ss.

García Valdés, El nuevo DP de los negocios y de las sociedades mercantiles; En Estudios jurídicos en Homenaje al prof. Aurelio Menéndez, t. IV, 1996, pp. 5121 ss.

García de Enterría, Los delitos societarios. Un enfoque mercantil, Madrid, Civitas, 1996.

Gómez Benítez, Administradores de hecho y de derecho en el nuevo Código penal, en: $A_{A} V v, E l$ nuevo Código penal. Delitos societarios e insolvencias punibles, Madrid, Banco Central Hispano, 1996, pp. 143 ss.; El delito de administración desleal: criterios diferenciadores con la apropiación indebida y los ilícitos mercantiles, LL 1997-1, pp. 2053-2056; y en: Asúa (coord.), Jornadas sobre el nuevo Código penal de 1995, Bilbao, Univ. País Vasco, 1998, pp. 155 ss.; De nuevo sobre la diferencia entre los delitos de apropiación indebida y administración desleal, LL 1998-6, pp. 2174-2177; Corrupción y delito de administración desleal, LL 2000-7, pp. 1283 ss.; Curso de DP de los negocios a través de casos: reflexiones sobre el desorden legal, Madrid, Colex, 2001; Delitos societarios, en: AaVv; Derecho penal económico. Manuales de Formación Continuada, 14, 2001, Madrid, CGPJ, pp. 563 ss.; Delitos societarios, en: González Rus (coord.), El Código Penal de 1995, cinco años después. Jornadas de Derecho Penal, Univ. Córdoba, 2002, pp. 55 ss.; Los delitos de apropiación indebida y disposición abusiva de los bienes sociales en el Código Penal y en la jurisprudencia, AJA 608, 2004, pp. 1 ss.

Gómez-Jara Díez (coord.), La administración desleal de los órganos societarios, Barcelona, Atelier, 2008.

Gómez Martín, La “actuación por otro" y la participación de extranei en delitos especiales. Un estudio sistemático de los arts. 31.1 y $65.3 \mathrm{CP}$, en LH-Cobo (Estudios penales en homenaje al Prof. Cobo del Rosal), Madrid, Dykinson, 2005, pp. 421-464; Los delitos especiales, Madrid, Edisofer / B de F, Montevideo-Buenos Aires, 2006, especialm. pp. 415 ss.

González Cussac, Delitos contra el patrimonio y el orden socioeconómico (XII): Delitos societarios, en Vives/Orts/Carbonell/González Cussac/ Martínez Buján, Derecho Penal, Parte Especial, 2004, 605 ss. 
González Rus, Delitos societarios, en Cobo (dir.), Curso de DP español, PE, I, Madrid, M. Pons, 1996, pp. 827 ss.; Delitos societarios, en Cobo (coord.), DP español, PE, 2. ${ }^{\text {a }}$ ed., Madrid, Dykinson, 2005, pp. 610 ss.

González Vizcaya, Los delitos societarios en el nuevo CP, APen 1997-1, pp. 229 ss. Hava García, Comentario a las Sentencias 1/1997 y 224/1998 ("Filesa" y "Argentia Trust"). Falsedad mercantil cometida por particular; apropiación indebida y administración desleal, RCP 1, 1998, pp. 548 ss.

Heredero, Los delitos financieros en la Jurisprudencia española, Barcelona, Bosch, 1969.

Hillenkamp, Risikogeschäft und Untreue, NStZ 1981, pp. 161 ss.

Jiménez Villarejo, De los delitos societarios y contra los consumidores, BICAM 1 1996 (3a época), pp. 9 ss.

Klug, Aktienstrafrecht, Berlinj, W. de Gruyter, 1975; Laвsch, Untreue (§ 266 StGB), Lübeck, Schmidt-Römhild, 1983.

López Barja de Quiroga, Problemas actuales de los delitos de estafa, fraude de subvenciones, apropiación indebida y administración desleal, en: $\mathrm{AAVv}$, Derecho penal económico, Manuales de Formación Continuada, 14, Madrid, CGPJ, 2001/2002, pp. 429 ss.

Luzón Cuesta, Compendio de DP, PE, Madrid, Dykinson, 16. ed., 2009, pp. 165 ss. Luzón Peña, Curso de Derecho Penal, Parte General I, Madrid, Universitas, 1996.

Luzón Peña/Roso Cañadillas, Administración Desleal, en Boix (dir.)/Lloria (coord.), Diccionario de Derecho Penal económico, Madrid, Iustel, 2008, pp. 29-68; Concurso entre apropiación indebida y administración desleal, en Boix (dir.)/ Lloria (coord.), Diccionario de Derecho Penal económico, 2008, pp. 181-203. Magaldi Paternostro, Los delitos societarios. Administración desleal y apropiación indebida: criterios delimitadores y relaciones entre ambas figuras, en: Gimeno Jubero (dir.); Derecho penal económico, Estudios de Derecho Judicial 72, 2005, pp. 135-191.

Marinucci/Romano, Techniche normative nella repressione penale degli abusi degli amministratori di società per azioni, RItDP 1971, pp. 681 ss.

Martínez-Buján Pérez, Delitos societarios: administración desleal, en Reforma penal y delitos contra el orden socio-económico. Actas XVI Curso de verano San Roque, Univ. Cádiz, 1995, pp. 45 ss.; Los delitos societarios de falsedades documentales y de administración fraudulenta, en: $\mathrm{AAVv}, \mathrm{E} 1$ nuevo $\mathrm{CP}$ y los delitos societarios, Fundación Caixa Galicia, 1998, pp. 202 ss.; Derecho penal económico, Parte especial, Valencia, Tirant lo Blanch, 1999, pp. 171 ss.; Derecho Penal económico y de la empresa, PE, 2a ed., 2005, pp. 454 ss.; El delito societario de administración desleal, Valencia, Tirant lo Blanch, 2001; Derecho penal económico, Valencia, Tirant lo Blanch, Tratados, 2002, pp. 267 ss.; Administración fraudulenta en sociedades de inversión, en Terradillos/ Acale (coords.), Temas de DP económico. III Encuentro Hispano-Italiano de DP económico, Madrid, Trotta, 2004, pp. 35 ss. 
Martínez Pérez (posteriormente Martínez-Buján Pérez), El delito societario de administración fraudulenta (Entre el delito patrimonial de la "infidelidad" y el delito societario del "abuso de facultades jurídico-sociales), EPCr XVII, 1994, pp. 261-352.

Martínez-Pereda Rodríguez, Los delitos societarios, en: AaVv, El nuevo Código penal y su aplicación a empresas y profesionales, tomo 4, Colecc. edit. por Diario Expansión, Madrid, 1996, pp. 347-382.

Mata y Martín, Los delitos societarios en el Código Penal de 1995, RDS, 5, 1995, pp. 164-176; Bienes jurídicos intermedios y delitos de peligro, Granada, Comares, 1997; Delitos societarios: administración desleal y demás figuras delictivas, CuadDJ 1998-5 (Empresa y Derecho penal I, dir p. del Rosal Blasco), pp. 337-408; Responsabilidad penal del administrador societario desleal. Estudio del art. 295 del CP, RDS 13, 1999, 2, pp.141-162; Estructura fundamental del delito de administración desleal, en: LH-Valle [Quintero Olivares/Morales Prats (coords.), El nuevo Derecho penal español. Estudios penales en memoria de Valle Muñiz], Navarra, Aranzadi, 2001, pp. 1545-1564.

Mayo Calderón, La tutela de un bien jurídico colectivo por el delito societario de administración fraudulenta. Estudio del art. 295 del Código Penal español y propuesta de lege ferenda, Granada, Comares, 2005.

Mazzacuva, Trattato di Diritto penale dell'impresa, II: I reati societari; Padova, Cedam, 1992; Sanciones administrativas y sanciones penales en materia de ilícitos societarios; en LH-Tiedemann, Madrid, BOE, 1995, pp. 681 ss.

Militello, I reati di infideltà, en Diritto penal e processo 6, 2002, pp. 698 ss.

Morales Prats, Dos cuestiones sobre delitos societarios: la frontera entre apropiación indebida y administración fraudulenta de sociedades, y el ámbito incriminador de los arts. 291 y 292, RDPP 2, 1999, pp.45 ss.

Moreno CÁnoves/ Ruíz Marco, Delitos socioeconómicos, Comentarios a los arts. 262, 270-310 del nuevo Código Penal (concordados y con jurisprudencia), Edijus, 1996;

Moya Jiménez, A., La responsabilidad penal de los administradores: Delitos societarios y otras formas delictivas, Barcelona 2007.

Muñoz Conde, Delitos societarios, en: Gómez Colomer/González Cussac, La reforma de la justicia penal, LH-Tiedemann, Castellón, Univ. Jaume I, 1997, pp. 137 ss.; Administración desleal e insolvencia punible: problemas de imputación personal, en LH-Barbero Santos. In memoriam, II, Univ. Catilla-LaMancha/ Univ. Salamanca, 2001, pp. 505 ss.; Derecho Penal, PE, 17. a , 2009, pp. 481 ss. Musco, I nuovi reati societari, Milano, Giuffrè, 2002.

Napoleoni, I reati societari, I: La tutela penale del capitale sociale; II: Infideltà ed abusi di podere, Milano, Giuffrè, 1991, 1992.

Nelles, Untreue zum Nachteil von Gesellschaften, Berlin, Duncker \& Humblot, 1991. Nieto Martín, El delito de administración fraudulenta, Barcelona, Praxis, 1996.

Olaizola Nogales, El caso de la construcción de Burgos. STS 18-1-1993 (RJ 1997/6482), en Sánchez Ostiz (coord.), 50 casos que hicieron doctrina, Madrid, La Ley, 2010 . 
Orts Berenguer, La administración fraudulenta de bienes en el Ordenamiento vigente y en el Proyecto de CP de 1994, CuadDJ 1995-11 (Falsedad y defraudaciones), pp. 213 ss.

Peñaranda Ramos, Sobre el alcance del art. 65.3 CP.Al mismo tiempo: una contribución a la crítica de la teoría de los delitos de infracción de deber, en: LH-Gimbernat (Estudios Penales en Homenaje a E. Gimbernat), Madrid, 2008, pp. 14191452.

Pérez Valero, Los distintos conceptos de delito societario del código penal de 1995, LL 2001-2, pp. 1653 ss.

Polo Vereda, Delitos societarios: reflexiones para una selección de aspectos polémicos, LL 1998-2, pp. 2044 ss.

Queralt, DP español, PE, 4. a ed. 2002, pp. 367 ss.

Quintero Olivares, Sobre los delitos societarios en el nuevo CP (Cuestiones generales), en: Asúa (coord.), Jornadas sobre el nuevo Código penal de 1995, Bilbao, Univ. País Vasco, 1998, pp. 165 ss.; Límites problemáticos: apropiación indebida, administración fraudulenta y falsedad documental, RDPP 1, 1999, pp. 41 ss.; El principio de intervención mínima y algunos delitos patrimoniales y societarios, en: LH-Valle Muñiz, Navarra, Aranzadi, 2001, pp. 1697 ss.

Quintero Olivares/Morales Prats, Comentario al art. 295, en: Quintero (dir.)/Morales (coord.), Comentarios al Nuevo CP, 3. ${ }^{\mathrm{a}}$ ed., Navarra, Aranzadi, 2004, pp. 1465-1474.

Ribas Ferrer, El deber de lealtad del administrador de sociedades, Las Rozas, Madrid, La Ley, 2010.

Ríos Corbacho, Aspectos controvertidos del delito de administración fraudulenta del patrimonio social, (art. 295 CP), RDPP 16, 2006, pp. 139-158.

Rodríguez Montañés, Algunas reflexiones acerca de los delitos societarios y las conductas de administración desleal, ADPCP 1996, pp. 424 ss.; La responsabilidad penal del administrador desleal y los nuevos delitos societarios, Madrid, McGrawHill, 1997; Algunas reflexiones acerca de sentencia del "Caso Argentia Trust” (STS 26-2-1998); TSJAP 3, 1998, pp. 9 ss.; Administración societaria fraudulenta y Derecho penal (Comentario a la SAN 31-3-2000, -Caso Banesto-), RDPCr 9, 2002, pp. 255-295; Delitos societarios, en Luzón Peña (dir.), EPB, 2002, pp. 545 ss.

Rodríguez Mourullo, Algunas consideraciones político-criminales sobre los delitos societarios, ADPCP 1984, pp. 677-691; Análisis del art. 294 del nuevo Código Penal, en: Aa Vv, El nuevo Código Penal. Delitos societarios e insolvencias punibles, Madrid, Banco Central Hispano 1996, pp. 126 ss.; El bien jurídico protegido en los delitos societarios con especial referencia a la administración desleal, en: CuadDJ 1999-7 (La administración desleal, dir. E. Bacigalupo), pp. 11 ss.; Consideraciones generales sobre los delitos societarios, AAMNot 44 2006, pp. 189 ss.

Rodríguez Ramos, Los nuevos delitos pseudosocietarios, en: BICAM, no 1 (3a época), 1996, pp. 71-95; Aspectos generales de los delitos societarios, en: Asúa (coord.), Jornadas sobre el nuevo Código penal de 1995, Bilbao, Univ. País 
Vasco, 1998, pp. 185 ss.; La administración desleal del art. 295 del Código Penal, en: CuadDJ 1999-7 (La administración desleal, dir. E. Bacigalupo), pp. 33 ss.

del Rosal Blasco, Capítulo XIII. De los delitos societarios, en Vives/y otros, Comentarios al CP de 1995, II, Valencia, Tirant, pp. 1404 ss; Los delitos societarios en el CP de 1995, Valencia, Tirant, 1998.

Ruiz Rodríguez, Protección penal del mercado de valores. Infidelidades en la gestión de patrimonios, Valencia, Tirant, 1997.

Samson/Günther, § 266, en: Rudolphi/Horn/Günther, Systematischer Kommentar zum StGB, t. 2, Besonderer Teil, 5. ${ }^{a}$ ed., 1996, pp. 125 ss..

Sánchez álvarez, Los delitos societarios, Pamplona, Aranzadi, 1996; Algunas reflexiones sobre el delito de administración societaria desleal del art. 295 del CP de 1995, LH-Valle Muñiz, Navarra, Aranzadi, 2001, pp. 1249 ss.

Schneider, Die Untreue nach dem neuen Aktienrecht, tesis doct. Bochum, München, 1972.

Schünemann, § 266 (Untreue), en StGB. Leipziger Kommentar, Grosskommentar, $11^{\text {a }}$ ed. 1998, 27. Lieferung; Sentr, Die aktienrechtliche Untreue in rechtsvergleichende Darstellung, Berlin, Frankfurt, Vahlen, 1965.

Seminara, El delito de infidelidad en la gestión de los intermediarios financieros, en Terradillos/Acale (coords.), Temas de DP económico. III Encuentro HispanoItaliano de DP económico, Madrid, Trotta, 2004, pp. 35 ss.

Sequeros Sazatornil, Los difusos contornos de los delitos societarios y su imprecisa frontera con otras conductas afines, APen 15, 2002, 1, nm.349 ss.; Delitos societarios y conductas afines (La responsabilidad penal y civil de la sociedad, sus socios y administradores), Las Rozas, Madrid, La Ley-Actualidad, 2003;

Serrano Butragueño, Los delitos societarios en el nuevo Código penal, AJA 48 1992, pp. 1 ss.

Serrano Gómez, Responsabilidad penal de administradores de sociedades y auditores de cuentas, APen 28, 1993, nm. 387 ss.

Serrano Gómez/Serrano MAÍLLo, Derecho Penal, PE, 14. a ed., Madrid, Dykinson, 2009, pp. 535 ss.; Silva Castaño, El delito de apropiación indebida y la administración desleal de dinero ajeno, Madrid, Dykinson 1997; Consolidación de la interpretación del delito de apropiación indebida y la administración desleal del patrimonio ajeno: el art. 252 del CP (Estudio de la STS de 26/0298: Caso Conde y el ATC 1295/98), en: Cancino (dir.), El DP español de fin de siglo. Estudios en homenaje a E. Bacigalupo, Bogotá, Gustavo Ibáñez, 1999, pp. 341 ss.; en: Bacigalupo (dir.), Curso de Derecho penal económico, 2.a ed., Madrid, Marcial Pons, 2005.

Silva Sánchez, Los delitos societarios en el Derecho Comparado, el Derecho vigente y el nuevo CP, en: El CP de 1995: Parte especial, Barcelona, CGPJ/Centre d'Estudis Jurídics i Formació Especialitzada, 1996, pp. 55 ss.

Suárez González, De los delitos societarios, en Rodríguez Mourullo (dir.)/Jorge Barreiro (coord.), Comentarios al CP, Madrid, Civitas, 1997,pp. 832 ss.; Delitos societarios, en: Bajo (dir.), Compendio de Derecho Penal. Parte Especial, II, 
Madrid, C.E. Ramón Areces, 1998, pp. 571 ss.; Aspectos político-criminales de los delitos socioeconómicos en el CP español, con especial referencia a los delitos societarios, en: Corcoy Bidasolo (dir.)/Lara González (coord.), Derecho penal de la empresa, Navarra, Aranzadi, 2002, pp. 209 ss.

Terradillos, Delitos financieros, DJ 37/40, 1983, 845-861; Delitos societarios. E1 Derecho penal en las sociedades mercantiles a la luz de nuestra adhesión a la CEE, Madrid, Akal/iure, 1987; Derecho Penal de la empresa, Madrid, Trotta, 1995; Los delitos societarios, en: del Rosal Blasco (ed.), Estudios sobre el nuevo CP de 1995, Valencia, Tirant, 1997, pp. 259 ss.; Delitos contra el orden socioeconómico: los nuevos delitos societarios, en: Asúa (coord.), Jornadas sobre el nuevo Código penal de 1995, Bilbao, Univ. País Vasco, 1998, pp. 195 ss.; Empresa y Derecho Penal, Buenos Aires, Ad Hoc, 2001.

Tiedemann, Wirtschaftsstrafrecht und Wirtschaftskriminalität, 2: Besonderer Teil, Reinbeck b.Hamburg, Rowohlt,1976; Lecciones de Derecho Penal Económico (comunitario, español, alemán), Barcelona, PPU, 1993; Vorbemerkung vor §§ 82 ff.: GmbH und Strafrecht, en: Kommentar zum GmbH-Strafrecht (§§ 8285 GmbHG und ergänzende Vorschriften), 3. ${ }^{a}$ ed., Köln, O. Schmidt, 1995, pp. 8 ss.

Valle Muñiz, De los delitos societarios, en: Quintero (dir.)/Morales (coord.), Comentarios a la Parte especial del Derecho penal, 2. ${ }^{a}$ ed., Navarra, Aranzadi, 1999, pp. 691-727.

Valle Muñiz/Quintero Olivares/Morales Prats, De los delitos societarios, en: Quintero (dir.)/Morales (coord.), Comentarios a la Parte especial del Derecho penal, 5. ${ }^{\mathrm{a}}$ ed., Navarra, Aranzadi, 2005, pp. 881-929.

Wassmer, Untreue bei Risikogeschäften, Heidelberg, Müller, 1997; Weber, Überlegungen zur Neugestaltung des Untreuestrafrechts; FS f. Dreher, Berlin, W. de Gruyter, 1977, pp. 555 ss.

Wodicka, Die Untreue zum Nachteil der $\mathrm{GmbH}$ bei vorheriger Zustimmung aller Gesellschafter, Frankfurt, Lang, 1993. 